\title{
Source apportionment of highly time-resolved elements during a firework episode from a rural freeway site in Switzerland
}

\author{
Pragati Rai $^{1}$, Markus Furger ${ }^{1}$, Jay G. Slowik ${ }^{1}$, Francesco Canonaco ${ }^{1}$, Roman Fröhlich ${ }^{1}$, Christoph Hüglin ${ }^{2}$, \\ María Cruz Minguillón ${ }^{3}$, Krag Petterson ${ }^{4}$, Urs Baltensperger ${ }^{1}$, and André S. H. Prévôt ${ }^{1}$ \\ ${ }^{1}$ Laboratory of Atmospheric Chemistry, Paul Scherrer Institute, 5232 Villigen PSI, Switzerland \\ ${ }^{2}$ Laboratory for Air Pollution/Environmental Technology, Empa, 8600 Dübendorf, Switzerland \\ ${ }^{3}$ Institute of Environmental Assessment and Water Research (IDAEA), CSIC, 08034 Barcelona, Spain \\ ${ }^{4}$ Cooper Environmental Services, Sailbri Cooper Inc., 10300 SW Nimbus Ave., Tigard, OR 97223, USA
}

Correspondence: André S. H. Prévôt (andre.prevot@psi.ch) and Markus Furger (markus.furger@psi.ch)

Received: 23 November 2018 - Discussion started: 21 January 2019

Revised: 9 December 2019 - Accepted: 19 December 2019 - Published: 11 February 2020

\begin{abstract}
The measurement of elements in $\mathrm{PM}_{10}$ was performed with $1 \mathrm{~h}$ time resolution at a rural freeway site during summer 2015 in Switzerland using the $\mathrm{Xact}^{1} 625$ Ambient Metals Monitor. On average the Xact elements (without accounting for oxygen and other associated elements) make up about $20 \%$ of the total $\mathrm{PM}_{10}$ mass $\left(14.6 \mu \mathrm{g} \mathrm{m}^{-3}\right)$. We conducted source apportionment by positive matrix factorisation (PMF) of the elemental mass measurable by the Xact (i.e. major elements heavier than $\mathrm{Al}$ ), defined here as $\mathrm{PM}_{10 \mathrm{el}}$. Eight different sources were identified in $\mathrm{PM}_{10 \mathrm{el}}$ (elemental $\mathrm{PM}_{10}$ ) mass driven by the sum of 14 elements (notable elements in brackets): Fireworks-I (K, S, Ba and Cl), FireworksII $(\mathrm{K})$, sea salt $(\mathrm{Cl})$, secondary sulfate $(\mathrm{S})$, background dust ( $\mathrm{Si}, \mathrm{Ti})$, road dust $(\mathrm{Ca})$, non-exhaust traffic-related elements ( $\mathrm{Fe})$ and industrial elements ( $\mathrm{Zn}$ and $\mathrm{Pb}$ ). The major components were secondary sulfate and non-exhaust traffic-related elements followed by background dust and road dust factors, explaining $21 \%, 20 \%, 18 \%$ and $16 \%$ of the analysed $\mathrm{PM}_{10}$ elemental mass, respectively, with the factor mass not corrected for oxygen content. Further, there were minor contributions (on the order of a few percent) of sea salt and industrial sources. The regionally influenced secondary sulfate factor showed negligible resuspension, and concentrations were similar throughout the day. The significant loads of the non-exhaust traffic-related and road dust factors with strong diurnal variations highlight the continuing importance of vehicle-related air pollutants at this site. Enhanced control
\end{abstract}

\footnotetext{
${ }^{1}$ Xact is a registered trademark of Cooper Environmental Services, LLC.
}

of PMF implemented via the SourceFinder software (SoFi Pro version 6.2, PSI, Switzerland) allowed for a successful apportionment of transient sources such as the two firework factors and sea salt, which remained mixed when analysed by unconstrained PMF.

\section{Introduction}

Ambient particulate matter (PM) plays a major role in affecting human health and air quality. Trace elements represent a minor fraction of the atmospheric aerosol on a mass basis, but they can act as specific markers for several emission sources. The short- or long-term exposure of ambient particulate matter (PM) has significant negative effects on human health (Dao et al., 2012; Ancelet et al., 2012; Zhao and Hopke, 2004; Pope III and Dockery, 2006; Dockery et al., 1993; Zhou et al., 2018). Cakmak et al. (2014) found significant association of acute changes in cardiovascular and respiratory physiology with $\mathrm{PM}_{2.5}$ metals in Ontario, Canada. In Stockholm, Meister et al. (2012) estimated a $1.7 \%$ increase in the daily mortality per $10 \mu \mathrm{g} \mathrm{m}^{-3}$ increase in the coarse fraction of PM. Metallic components of PM, especially the fine fraction of elements such as $\mathrm{Fe}, \mathrm{Ni}, \mathrm{Cu}, \mathrm{V}, \mathrm{Pb}$ and $\mathrm{Zn}$, appear to be a significant cause of both pulmonary and cardiovascular diseases (Kelly and Fussell, 2012). Airborne particles and associated (trace) elements originate from various emission sources, such as motor vehicles, power plants and construction activities, in a broad size range. Among them, 
traffic-related emissions are of particular interest (Brauer et al., 2002). Traffic-derived PM has a high risk of respiratory illness, asthma and cardiovascular diseases, resulting in an increased rate in mortality (Kelly and Fussell, 2011). Trafficrelated PM is emitted mainly as exhaust emissions (tailpipe exhaust from gasoline and diesel engines) and non-exhaust emissions (resuspension of road dust and brake and tire wear emissions; Lawrence et al., 2013; Lin et al., 2015; Thorpe and Harrison, 2008; Zhou et al., 2018; Grigoratos and Martini, 2015; Amato et al., 2014b; Bukowiecki et al., 2010). Exhaust emissions are predominantly in the fine fraction of PM, whereas non-exhaust emissions contribute mostly to the coarse fraction (Amato et al., 2011; Thorpe and Harrison, 2008). Exhaust emission-related elements are comprised of $\mathrm{Pb}, \mathrm{Zn}, \mathrm{Ni}$ and V (Lin et al., 2015; Minguillón et al., 2012), while the non-exhaust emissions are dominated by $\mathrm{Fe}, \mathrm{Cu}$, $\mathrm{Ba}, \mathrm{Ca}, \mathrm{Sb}, \mathrm{Sn}, \mathrm{Cr}$ and $\mathrm{Zn}$ from brake lining and tire wear. The presence of $\mathrm{Fe}$ in brake lining can reach up to $60 \%$ by weight (Chan and Stachowiak, 2004; Schauer et al., 2006). Brake pads are usually filled with $\mathrm{BaSO}_{4}$, while $\mathrm{Sb}, \mathrm{Sn}$ and Mo sulfides are often added as lubricants, and $\mathrm{Cu}, \mathrm{Cr}$ and $\mathrm{Zn}$ are major additives to lubricating oils and normally used to improve friction (Thorpe and Harrison, 2008; Amato et al., 2014a). Sb has been identified as a major tracer of brake wear, due to a significant $(1 \%-5 \%)$ percentage of $\mathrm{Sb}$ in brake linings in the form of stibnite $\left(\mathrm{Sb}_{2} \mathrm{~S}_{3}\right.$; Grigoratos and Martini, 2015; Bukowiecki et al., 2009). It has been reported that asphalt pavement-induced particles were characterised mainly by high concentrations of $\mathrm{Cu}, \mathrm{Cr}, \mathrm{Ni}, \mathrm{As}$ and $\mathrm{Pb}(\mathrm{Yu}$, et al., 2013) as well as $\mathrm{Ca}, \mathrm{Si}, \mathrm{Mg}, \mathrm{Al}, \mathrm{Fe}, \mathrm{P}, \mathrm{S}, \mathrm{Cl}, \mathrm{K}, \mathrm{V}$, $\mathrm{Mn}$ and $\mathrm{Na}$ (Fullova et al., 2017). Therefore, it is important to monitor traffic emissions for health risk assessment, the study of which relies heavily on the source apportionment (SA) of PM using chemically speciated data (Zhou et al., 2018).

Source quantification and characterisation is an important step in understanding the relationship between source emissions, ambient concentrations, and health and environmental effects. SA by receptor models has been widely used in recent years to identify and apportion the contributions of various sources to the airborne PM concentrations. Positive matrix factorisation (PMF) is one of the most widely used receptor models for SA of trace elements (Rahman et al., 2011; Ancelet et al., 2012; Cesari et al., 2014; DucretStich et al., 2013; Kim et al., 2003; Rai et al., 2016; Zhang et al., 2013; Harrison et al., 2011; Hedberg et al., 2005). However, a limited number of studies are available for traceelement emission sources with high time resolution (hourly or sub-hourly; Visser et al., 2015; Crilley et al., 2016; Bukowiecki et al., 2010; Richard et al., 2011; Dall'Osto et al., 2013; Manousakas et al., 2015; Jeong et al., 2019; Wang et al., 2018, among others). Hourly elements data can be used to explore the diurnal patterns of emissions from traffic, biomass burning and industrial sources, thereby yielding more accurate and exposure-relevant SA results. Currently, there are very few offline instruments available for field sampling of elements with high time resolution, such as the rotating drum impactor (RDI; Bukowiecki et al., 2008), the streaker sampler (PIXE International Corporation; Lucarelli et al., 2011) and the semi-continuous elements in aerosol sampler (SEAS; Kidwell and Ondov, 2001). The large quantity of samples generated by these samplers requires a labourintensive and time-consuming offline analysis. These offline analyses require high-precision and low-detection-limit techniques such as synchrotron-radiation-induced X-ray fluorescence spectrometry (SR-XRF) of aerosol samples collected with a RDI, particle-induced X-ray emission (PIXE) with the streaker sampler and graphite furnace atomic absorption spectrometry (GFAAS) with the SEAS. In practice, the offline samplers lead to undesirable trade-offs between time resolution and data coverage even for short duration field campaigns, whereas highly time-resolved long-term measurements are impractical. A recently introduced online high-time-resolution instrument can collect samples and perform analysis for elements simultaneously in a near-realtime scenario for long-term measurements without waiting for laboratory analysis. The XRF-based Xact 620, Xact 625 and the newer Xact 625i Ambient Metals monitors (Cooper Environmental Services, Tigard, Oregon, USA) have been developed in recent years and have been used in several field studies (Fang et al., 2015; Cooper et al., 2010; Furger et al., 2017; Park et al., 2014; Phillips-Smith et al., 2017; Tremper et al., 2018; Chang et al., 2018; Liu et al., 2019). However, only 10 studies included SA on Xact data (Park et al., 2014; Fang et al., 2015; Phillips-Smith et al., 2017; Chang et al., 2018; Liu et al., 2019; Ji et al., 2018; Sofowote et al., 2018; Jeong et al., 2019; Belis et al., 2019b; Cui et al., 2019).

The main focus of this work is the exploration of the use of the Xact for source apportionment in Europe, where the concentrations are considerably lower than in polluted areas in Asia. In the present study, we conducted SA using PMF to characterise the source contributions of highly time-resolved metals during a 3-week campaign at a trafficinfluenced site in Härkingen, Switzerland. PMF was implemented through the multilinear engine-2 (ME-2) solver and controlled via SoFi, which allows for a comprehensive and systematic exploration of the solution space (Bozzetti et al., 2016; Canonaco et al., 2013). The rotational control available in ME-2 provides a means for treating extreme events such as fireworks within a PMF analysis. Such events are often excluded from the PMF input matrix to avoid modelling errors due to the pulling of a solution by outliers (Ducret-Stich et al., 2013; Norris et al., 2014). Although a few studies have already been carried out in the past at this location (Lanz et al., 2010; Hueglin et al., 2006; Furger et al., 2017), none of them have reported SA on elements. 


\section{Experimental setup and data analysis}

\subsection{Sampling location}

$\mathrm{PM}_{10}$ sampling was performed from 23 July to 13 August 2015 in Härkingen, Switzerland, a permanent station of the Swiss National Air Pollution Monitoring Network (NABEL; Fig. 1). Extreme firework episodes were captured during the Swiss National Day celebration (1 August). The site is situated next to the A1 freeway, which is the main traffic route between eastern (Zurich) and western (Bern) Switzerland. The measurement site is bordered by agricultural areas to the west and north, while there are villages in the southern and eastern direction. There is a metal processing company to the south-east, across the freeway, which manufactures wheels for passenger cars and commercial vehicles, and some small-scale industrial buildings to the north-west. The emissions reaching the measurement site depend on wind direction. The site is strongly influenced by local road traffic emissions when winds come from the southern sector, while the northern wind sector represents the air constituents from a rural area. A detailed description of the sampling site can be found in previous studies (Furger et al., 2017; Hueglin et al., 2006).

\subsection{Sampling and analysis}

Sampling and analysis was conducted with an Xact 625 Ambient Metals Monitor equipped with a $\mathrm{PM}_{10}$ inlet. The instrument was set up to quantify 24 elements $(\mathrm{Si}, \mathrm{S}, \mathrm{Cl}, \mathrm{K}$, $\mathrm{Ca}, \mathrm{Ti}, \mathrm{V}, \mathrm{Cr}, \mathrm{Mn}, \mathrm{Fe}, \mathrm{Co}, \mathrm{Ni}, \mathrm{Cu}, \mathrm{Zn}, \mathrm{As}, \mathrm{Se}, \mathrm{Cd}, \mathrm{Sn}$, $\mathrm{Sb}, \mathrm{Ba}, \mathrm{Pt}, \mathrm{Hg}, \mathrm{Pb}$ and $\mathrm{Bi}$ ) with $1 \mathrm{~h}$ time resolution. In addition, $24 \mathrm{~h} \mathrm{PM}_{10}$ samples were collected by a HiVol sampler (Digitel DA-80H, DIGITEL Hegnau, Switzerland) with quartz-fibre filters (Pallflex XP56 Tissuquartz 2500QAT-UP, Pall AG, Switzerland). Ten of these $24 \mathrm{~h} \mathrm{PM}_{10}$ samples were analysed by inductively coupled plasma optical emission spectrometry (ICP-OES) for the concentrations of $\mathrm{Na}$, $\mathrm{Mg}, \mathrm{Al}, \mathrm{P}, \mathrm{S}, \mathrm{K}, \mathrm{Ca}$, Ti and Fe. Moreover, the station was equipped with other instruments such as a tapered element oscillating microbalance-filter dynamics measurement system (TEOM FDMS 8500, Thermo Fisher Scientific, MA, USA) for $10 \mathrm{~min} \mathrm{PM}_{10}$ mass concentration measurements, a multi-angle absorption photometer (MAAP, Thermo 5012, Thermo Fisher Scientific, MA, USA) for black carbon (BC) measurements in $\mathrm{PM}_{2.5}$ and standard meteorological sensors (temperature, wind speed and direction, and precipitation). The trace gases were measured with conventional instruments by NABEL (Empa, 2018). $\mathrm{NO}_{x}$ was measured by chemiluminescence spectroscopy (Horiba APNA-370). The time resolution of all these instruments was $10 \mathrm{~min}$. The station also provided hourly traffic counts for the freeway in the form of the total number of vehicles, number of heavy-duty vehicles (HDVs) and number of light-duty vehicles (LDVs). Specifically for the campaign, a quadrupole aerosol chem- ical speciation monitor (Q-ACSM 140-145, Aerodyne Inc, Billerica, MA, USA) with vacuum aerodynamic diameters smaller than $1 \mu \mathrm{m}$ (non-refractory $\mathrm{PM}_{1}$ ) was deployed $(\mathrm{Ng}$ et al., 2011; Crenn et al., 2015), and the data were used for comparison of the factors during the SA analysis. The time resolution of the ACSM was set to $30 \mathrm{~min}$.

\subsection{PMF using ME-2}

Positive matrix factorisation is one of the most common receptor models based on a weighted least-squares fit (Paatero and Tapper, 1994). It is used to describe the variability in a multivariate dataset as the linear combination of a set of constant factor profiles and their corresponding time series as shown in Eq. (1) in cell notation:

$x_{i j}=\sum_{k=1}^{p} g_{i k} f_{k j}+e_{i j}$,

where $x_{i j}, g_{i k}, f_{k j}$ and $e_{i j}$ represent the elements of the data matrix, factor time series, factor profiles and residual matrices, respectively, while $i, j$ and $k$ indices denote time, element and factor number. The index $p$ represents the total number of factors in the PMF solution. The PMF model iteratively solves Eq. (1) by minimising the object function $(Q)$, defined as

$Q=\sum_{i} \sum_{j}\left(\frac{e_{i j}}{s_{i j}}\right)^{2}$

Here, $s_{i j}$ corresponds to the measurement uncertainty (error matrix) for the input point $i j$.

The PMF algorithm was solved using ME-2 (Paatero, 1999), which enables an efficient exploration of the solution space by introducing a priori information to $g_{i k}$ and/or $f_{k j}$ into the PMF model. Using the constraining technique of the $a$ value, one or more factor profiles or factor time series can be confined by the scalar $a(0 \leq a \leq 1)$, which can be applied to the entire profile or time series or to individual variables and data points of the profile and time series. The scalar $a$ defines how much the resolved factors are allowed to deviate from the input profile or time series, according to

${f^{\prime}}_{k j}=f_{k j} \pm a \times f_{k j}$,

$g^{\prime}{ }_{i k}=g_{i k} \pm a \times g_{i k}$,

where the subscript $j$ varies between 0 and the number of variables and $i$ varies between 0 and the number of measured data points in time. $f_{k j}$ and $g_{i k}$ are the starting value used as a priori knowledge from the base case solution in this SA study, and $f^{\prime}{ }_{k j}$ and $g^{\prime}{ }_{i k}$ are the resulting values in the solution. Normalisation in Eqs. (3) and (4) can lead to the resulting values slightly outside the specified $a$-value boundaries. This method reduces the available solution space and directs the solution towards an optimised and environmentally meaningful solution. The SoFi Pro (Canonaco et al., 2013), which is coded in the Igor Pro software environment (Wavemetrics, Inc., Portland, OR, USA), was used for the PMF configuration and analysis. 


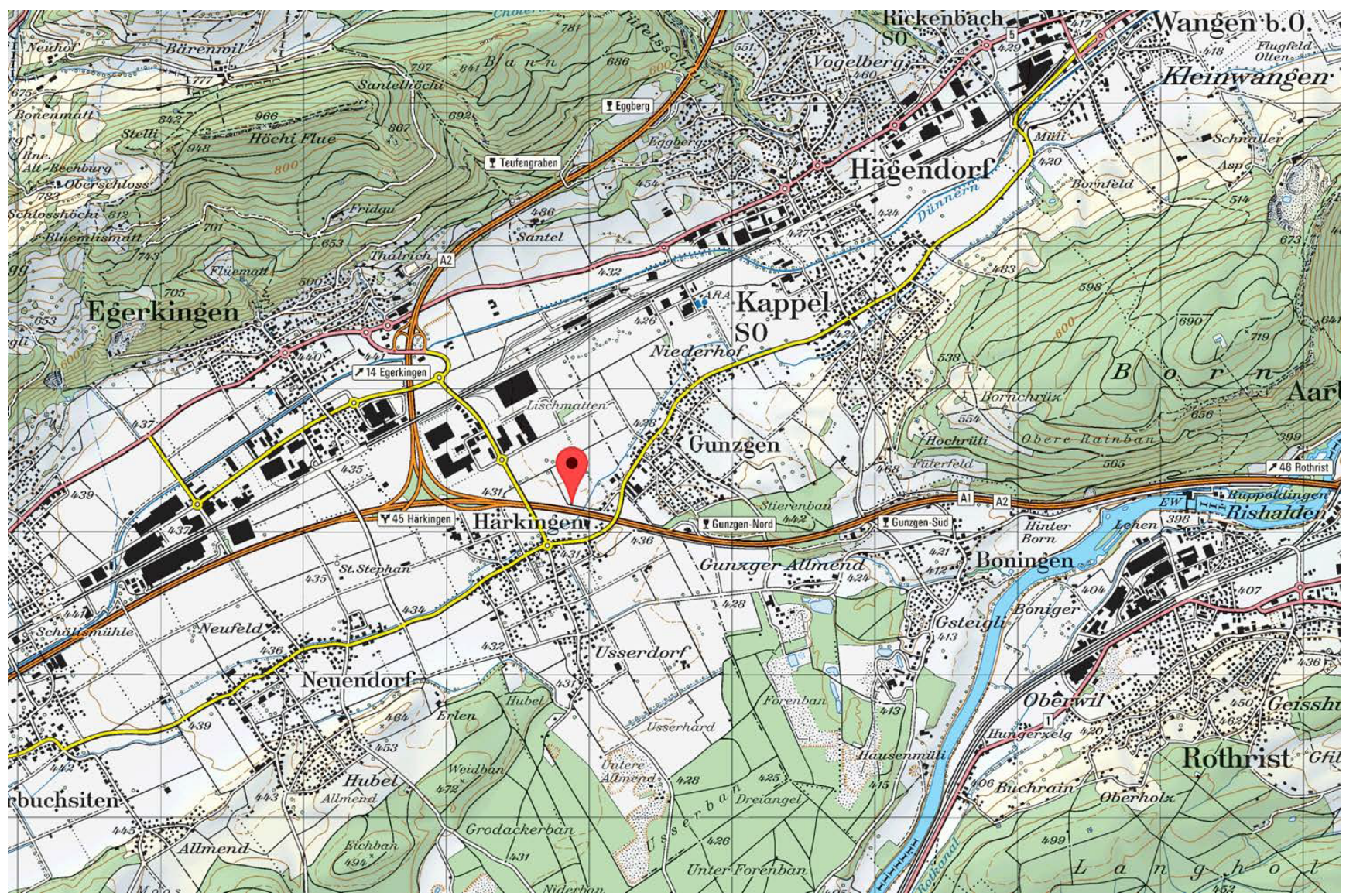

Figure 1. Map of the sampling location (NABEL site in Härkingen). The site is marked with the red Google pin. Map reproduced by permission of swisstopo (JA100119).

\subsection{Conditional bivariate probability function (CBPF) plots}

The conditional bivariate probability function (CBPF) is a data analysis tool to identify the direction of source contributions and was applied to the PMF source factors. Polar plots are used to present the CBPF analyses, where the number of events with a concentration greater than the $i$ th percentile $(0$ to 100) is plotted as a function of both wind speed and direction, as shown in Eq. (5):

$\mathrm{CBPF}=\frac{m_{\theta, r}}{n_{\theta, r}}$,

where $m_{\theta, r}$ is the number of samples in wind sector $\theta$ and wind speed sector $r$ with a concentration greater than the $i$ th percentile and $n_{\theta, r}$ is the total number of samples with the same wind direction and speed (Carslaw and Beevers, 2013). The resultant CBPF polar plots present the probability that high concentrations of a pollutant correspond to a particular wind direction and speed and can give insight into the contributions from local and regional sources.

\section{SA method and solution selection}

\subsection{PMF input preparation}

In our study, the PMF input consists of a data matrix and an error matrix of hourly element measurements, where the rows represent the time series (456 points with $1 \mathrm{~h}$ steps) and the columns contain the elements (14 variables). The input preparation of PMF was done by excluding some specific elements for better source apportionment results. A common approach for the choice of species to include in the PMF input depends on (1) the percentage of data below the detection limit (Polissar et al., 1998) and (2) Xact data comparison with offline $24 \mathrm{~h} \mathrm{PM} 10$ filters (Pearson coefficient of determination $r^{2}$ ). The minimum detection limits (MDLs), $r^{2}$ and data points below the MDL of Xact elements are listed in Furger et al. (2017). The MDLs were given by the manufacturer and were calculated by using the sensitivity of the element and counts in the region of interest of a blank section of the tape from where $1 \sigma$ interference-free detection limits are reported. Elements (\% of data points below the MDL; $r^{2}$ value) which had more than $50 \%$ of data points below the MDL and a low $r^{2}(<0.5)$ between Xact and offline data 
were not included in the PMF input; these include the following: V (98\%; 0.57), Co (100\%; 0.05), Ni (32\%; 0.22), As $(96 \% ; 0.5)$, Se $(62 \% ; 0.3)$, Cd (87\%; 0.18), Sn (15\%; $0.27), \mathrm{Sb}(6 \% ; 0.42), \mathrm{Hg}(13 \% ; 0.12)$ and $\mathrm{Pt}(98 \%$; not measured on the filters). The element $\mathrm{Bi}$ (93\% data points below the MDL) was an exception to include in the PMF input due to an excellent correlation between Xact and offline data $\left(r^{2}=0.98\right)$ during firework peaks. The detailed description of the Xact data quality is given in the previous study (Furger et al., 2017). Missing data points in time (e.g,. a power failure during sampling or a filter tape change) were removed from the data and error matrices. In the present work, if the element concentration was less than or equal to the MDL provided, the error matrix element $s_{i j}$ was calculated using the Eq. (6), and if the concentration was greater than the MDL provided, the error matrix element $s_{i j}$ was calculated using Eq. (7) (Reff et al., 2007; Tian et al., 2016; Polissar et al., 1998):

$s_{i j}=\frac{5}{6} \times \mathrm{MDL}_{j}$,

$s_{i j}=\sqrt{\left(p_{j} \times x_{i j}\right)^{2}+\left(\mathrm{MDL}_{j}\right)^{2}}$,

where $x_{i j}$ indicates the elements of the data matrix, while subscripts $i$ and $j$ are indices for time and elements. In this study, an estimated analytical uncertainty $\left(p_{j}\right)$ of $10 \%$ was used to derive the error matrix dataset (Kim et al., 2005; Kim and Hopke, 2007; Tian et al., 2016; Ji et al., 2018), which did not change the PMF solution. The metal-specific analytical uncertainty was also considered from the previous studies (Jeong et al., 2016; Phillips-Smith et al., 2017), where it was calculated on the basis of high- or mediumconcentration metal standard laboratory experiments and the additional 5\%-10\% flow rate accuracy, which yielded similar PMF solutions compared to an overall $10 \%$ analytical uncertainty.

\subsection{PMF setup}

An important step in the PMF analysis is the selection of the number of factors by the user, as mathematical diagnostics alone are insufficient for choosing the correct number of factors (Ulbrich et al., 2009; Canonaco et al., 2013). The selection of factors is often based on an analysis of total $Q$ or $Q / Q_{\text {exp }}$, scaled residuals $\left(e_{i j} / s_{i j}\right)$, comparison of time series of the factor with external tracers, as well as diurnal patterns, and the evaluation of the residual time series as a function of the number of resolved factors.

In a first step, we examined a range of solutions with 310 factors at 10 seeds (number of PMF repeats) from unconstrained runs. The unconstrained PMF solution resulted in mixed factors, such as sea salt mixed with fireworks, in all factor solutions. We show an example of a mixed ninefactor solution in Fig. S1 in the Supplement. This is likely because of the very high concentration and variation in composition of firework emissions during the firework period.
Because the signal-to-noise ratio is very high, imperfections in the model description exert a strong influence on $Q$, and the model therefore tries to compensate by assigning firework mass to other factors. This was particularly evident for the sea salt and secondary sulfate factors, where constraints on factor profiles and/or time series were necessary to obtain clean separation. Here we discuss the method for achieving this separation.

The input dataset was divided into two parts: firework days (FDs; 31 July-4 August) and non-firework days (NFDs; all days except 31 July-4 August). To obtain a specific firework profile, we further selected only firework hours (FHs; 31 July 21:00 LT-1 August 07:00 LT (local time is coordinated universal time $+2 \mathrm{~h}$ ) as input data. The PMF analysis was performed on the NFDs, FDs, FHs and the complete datasets separately for 3-10 factors, with each of these solutions investigated with different seeds (each seed represents a different random initialisation).

The unconstrained NFD PMF analysis resolved seven factors at all seeds, such as sea salt, secondary sulfate, a nonexhaust traffic-related factor, road dust, background dust, an industrial factor and a K-rich factor. The sea salt factor profile shows excellent correlation $\left(r^{2}=0.99\right)$ between the $\mathrm{Cl}$ and the identified sea salt factor time series. Solutions with fewer than seven factors showed significant scaled residuals for elements and time series, while solutions with more than seven factors revealed a split of the non-exhaust trafficrelated factor and industrial and background dust factors. The NFD analysis therefore provides a sea salt profile that can be used as a constraint in the complete dataset.

The unconstrained PMF analysis of the complete dataset identified a secondary sulfate factor (most of the $\mathrm{S}$ is apportioned in this factor, with $91 \%$ of the factor mass) in the nine-factor solution (Fig. S1). The identified secondary sulfate factor time series correlated very well with ACSM sulfate $\left(r^{2}=0.91\right.$; Fig. S1) at 24 seeds out of 100 seeds, while $r^{2}$ was $\leq 0.88$ for the remaining 76 seeds. Although these $r^{2}$ are quite similar at all 100 seeds, the solution characteristics are notably different at 24 seeds $\left(r^{2}=0.91\right)$ and 76 seeds $\left(r^{2} \leq 0.88\right)$. For the nine-factor solution shown in Fig. S1, the secondary sulfate factor was slightly enhanced, which is in agreement with the ACSM sulfate, during the firework peaks (see details in Sect. 4.2: "Secondary sulfate"), while the sea salt factor was strongly enhanced during the firework peaks. In contrast, for the solutions at 76 seeds, visible contamination (i.e. concentration spikes) during the firework plumes were observed in the secondary sulfate factor, suggesting mathematical mixing. S is one of the major components of firework emissions, the composition of which is highly variable. Because of their high sensitivity (and thus high signalto-uncertainty ratio), imperfections in the model description of the firework composition yield high-signal residuals which strongly influence $Q$. The model responds by apportioning firework residuals to the other factors during the firework days. A similar issue also occurred for the sea salt factor due 
to the significant amount of $\mathrm{Cl}$ in the firework factor profile. Therefore, such events are often excluded from traditional PMF analyses (i.e. time periods removed from the input matrix) to avoid modelling errors due to the pulling of a solution by outliers. Here we take a different approach, exploiting the rotational control available in ME-2 to isolate environmentally reasonable, unmixed solutions. The $Q / Q_{\exp }$ values for all 100 seeds were in the range of $0.41-0.45$ (Fig. S2). The scaled residual (over the time series) of $\mathrm{S}$ in this solution (Fig. S1) was within the range of \pm 3 , with very small values, as shown in Fig. S3. The strong influence of fireworks in this solution yielded small values of the scaled residual for $\mathrm{S}$ which are consistent also with lower-than-expected $Q / Q_{\text {exp }}$ (0.4) values, suggesting an overestimation of uncertainties by the generic error model used herein (see Eqs. 6 and 7).

We then performed the constrained PMF analysis on the FD and FH datasets. Here we constrained the secondary sulfate factor profile ( $a$ value 0.1 ) and the time series ( $a$ value 0.01) using the results of the nine-factor unconstrained PMF analysis of the complete dataset. We tested several approaches for the secondary sulfate constraint: (a) constraining the factor profile only, (b) constraining the factor time series during firework days only, (c) constraining both the factor profile and the entire factor time series, and (d) constraining the factor profile and the factor time series during firework days only. Of the above methods, only (c) and (d) yielded secondary sulfate factors without visible mixing from the firework period. Approach (d) was used for PMF analysis, as it provides maximum freedom to the algorithm.

In the FD and FH PMF analyses, the sea salt factor profile ( $a$ value 0.1 ) was also constrained from the NFD unconstrained seven-factor PMF analysis. To resolve the unmixed sea salt factor time series from the fireworks, the background $\mathrm{Cl}$ concentration was calculated for the firework data points $\left(\mathrm{K}>220 \mathrm{ng} \mathrm{m}^{-3}\right.$ ) only. A Cl concentration $<30 \mathrm{ng} \mathrm{m}^{-3}$ was considered to be a background $\mathrm{Cl}$ concentration, and the firework data points were replaced with the linear interpolation between the background $\mathrm{Cl}$ concentrations adjacent to the firework peaks. In this way $42 \%$ of the data points were interpolated during the firework days. The calculated background $\mathrm{Cl}$ during the FDs was constrained (with an $a$ value of 0.01) in the sea salt factor time series. After applying all the four constraints, the FH PMF analysis identified a firework factor profile on the basis of the $\mathrm{K} / \mathrm{S}$ elemental concentration ratio $(\sim 2.76)$ in black powder (Dutcher et al., 1999) and the concentration peak of $42 \mu \mathrm{g} \mathrm{m}^{-3}$, which is close to the total elemental concentration peak of $48.4 \mu \mathrm{g} \mathrm{m}^{-3}$ on 1 August at 23:00 LT in the factor time series. The FD PMF analysis also identified a firework factor, but the highest peak was $30 \mu \mathrm{g} \mathrm{m}^{-3}$ on 1 August 23:00 LT in the factor time series and the K/S elemental concentration ratio was 2.55 in the factor profile. Therefore, the firework factor profile from FH PMF analysis was considered for the final complete dataset PMF analysis. The FD and FH PMF analyses resolved a five-factor solution, with secondary sulfate, sea salt, fireworks, back- ground dust and a K-rich factor with firework-related elements. In the K-rich factor, the $\mathrm{K} / \mathrm{S}$ ratio was slightly higher (3.56) than the black powder ratio. The unconstrained FH PMF analysis was also performed for two to five factors with different seeds. As shown in Fig. S4, the constrained fivefactor $Q / Q_{\exp }$ is 1.5 , which is $\sim 3$ times higher than the unconstrained five-factor $Q / Q_{\exp }$ but the same as the unconstrained 3-factor $Q / Q_{\exp }$ (1.52). The increase in $Q$ for the constrained five-factor FH PMF (unexplained variation - UEV - for each variable is between $2 \%$ and $16 \%$ with an average $\sim 10 \%$ ) is significant when compared to the unconstrained five-factor FH PMF (UEV for each variable is between $1.5 \%$ to $15 \%$ with an average $\sim 5 \%$ ), as shown in Fig. S5. The three-factor unconstrained FH PMF analysis validates the five-factor constrained FH PMF analysis, which suggests that both methods are working fine and gives us more confidence to identify the firework factor profile.

Note that the number of time points contained in the input matrices for the data subsets (as opposed to the full dataset) are in some cases smaller than typical recommendations for ambient PMF (Belis et al., 2019a). This is most extreme in the case of the FH dataset, where only 11 time points are used. However, there are two important differences between PMF analyses of these sub-datasets and typical ambient PMF: (1) the sub-datasets are constructed to maximise the variability in a factor or set of factors, and (2) we are concerned only with accurately characterising the profile(s) of these selected major factors. These two points work together to greatly reduce the number of time points required for the analysis (Fig. S6). A similar approach has been successfully applied by Fröhlich et al. (2015), in which shortduration spikes in organic aerosol concentration were combined into a sub-dataset to determine an anchor profile related to local cigarette smoke, and by Visser et al. (2015), in which a subset of a trace-element dataset with high residuals was analysed separately to retrieve a factor profile related to industrial emissions. In the final complete dataset PMF analysis, the factor profiles of fireworks, secondary sulfate and sea salt were constrained ( $a$ value 0.1 ), while the time series of secondary sulfate and the calculated background $\mathrm{Cl}$ concentration interpolation were constrained during the firework period only ( $a$ value 0.01 ). The solution that best represented the input data was an eight-factor solution, consisting of factors interpreted as sea salt, secondary sulfate, a non-exhaust traffic-related factor, an industrial factor, and two dust-related and two firework-related factors.

Residual analysis ( $Q$ contribution over time series) of the PMF runs showed significant structure in the residuals $(Q$ maximum value was 15 during firework period as shown in Fig. S8) for solutions having up to seven factors. Increasing the number of factors to eight gave evidence of structure removal, with mostly random errors remaining, by another Fireworks-II factor which was explained by $\mathrm{K}, \mathrm{S}, \mathrm{Ba}, \mathrm{Ti}, \mathrm{Cu}$ and Bi (see details in Figs. S8 and S9), while a further increase led to a new mixed factor of the non-exhaust traffic- 
related factor and background dust, which, however, showed a noisy diurnal pattern. All the variables showed approximately unimodal scaled residuals between -3 and 3 (Paatero and Hopke, 2003; Fig. S10).

\subsection{Uncertainty estimate of PMF results}

The statistical and rotational uncertainties were explored by the bootstrap (BS) resampling strategy (Efron, 1979) and the exploration of the $a$ value space of the constrained information as well as random initialisation of the unconstrained information. Briefly, the bootstrap algorithm generates new input matrices by randomly resampling variables from the original input matrix. Each newly generated PMF input matrix had a total number of samples equal to the original matrix (456 samples); although some of the original 456 samples were represented several times, others were not represented at all. A systematic investigation of the $a$-value space in combination with each individual BS run is computationally impractical and was therefore replaced by random initialisation of the $a$ value of the secondary sulfate, sea salt and Fireworks-I factor profiles between 0 and 0.5 with an increment of 0.1 for 1000 BS runs. Moreover, to avoid rejection of many solutions due to mixing of the sea salt factor time series and the secondary sulfate time series with the firework factor peaks, both the sea salt and secondary factor time series (for the firework period only) were also constrained with an $a$ value 0.01 . The small $a$ value (0.01) for the sea salt and the secondary sulfate factor time series (for the firework period only) were estimated based on sensitivity analyses on the $a$ value from 0 to 0.1 with an increment of 0.01 . The time series of both factors showed firework peaks during the firework period for $a$ values greater than 0.01. Solutions were selected and retained based on the correlation (Pearson correlation coefficient $r$ ) of the time series between the factors of the base case and the factors of the BS runs. Solutions with low correlation and some solutions with high correlation have a factor of a completely different type, i.e. a mixed, split or otherwise-altered factor profile and time series based on visual inspection. These kinds of solutions were rejected. This approach was used only for uncertainty assessment rather than uncertainty exploration to find the environmentally reasonable solution.

We also performed separate random bootstrap analyses for 1000 times on the correlation $(r)$ between the time series of a base case factor and the respective external marker, e.g. the secondary sulfate factor vs. ACSM sulfate, and the nonexhaust traffic-related factor vs. $\mathrm{NO}_{x}$ to assess the acceptable uncertainty of the $r$ value. The resulting correlation coefficients were represented in probability density functions (PDFs) over 1000 bootstrap runs for both bootstrap analysis methods. In total $86 \%$ of the bootstrap runs were classified as environmentally good solutions. The average $a$ value retained by the selected bootstrap runs was $0.233,0.255$ and 0.241 for the Fireworks-I, sea salt and secondary sulfate fac- tor profiles, respectively. The spread of the $a$ value for these three factors is presented as the mean, median and interquartile in Fig. S11. The selected solutions' factor profiles are represented as a box-whisker plot in the sequence of p10 (10th percentile), p25 (25th percentile), p50 or median (50th percentile), p75 (75th percentile), and p90 (90th percentile) in Fig. 2.

During the non-firework period, uncertainties in the source apportionment results are assessed by a bootstrap analysis as described above. However, this approach cannot be used to assess uncertainties in the sea salt and secondary sulfate factors during the firework period, as during this period these factor time series are constrained with an artificially low $a$ value selected to optimise deconvolution. For these two factors, uncertainties during the firework period are determined by our ability to accurately predict the factor time series. The secondary sulfate and sea salt factors' cases are discussed separately below.

Secondary sulfate concentrations during the firework period were estimated from the linear fit of the secondary sulfate factor to ACSM sulfate during the entire non-firework period. Uncertainties of $\pm 5 \%$ were calculated as the standard deviation of the actual secondary sulfate concentrations to the predicted values and included for the firework period only in Figs. 3a and S12.

As described above, the sea salt factor time series during the $4 \mathrm{~d}$ firework period was investigated to determine measurements that were affected or not affected by fireworks, where the measurements determined to be affected were replaced with a linear interpolation between the nearest good points. To determine the uncertainties of this approach, we applied this calculation to random segments of the non-firework data. Specifically, the $4 \mathrm{~d}$ long sequence of affected or non-affected time points determined during the firework period was applied to a randomly chosen segment of data, and the standard deviation of measurement data to the estimated values calculated by interpolation was determined. This analysis was repeated for 38 randomly selected locations through the non-firework data, and a mean standard deviation of $\pm 42 \%$ was determined. This value is used as the uncertainty of the sea salt factor time series (during the firework period only) in Figs. 3a and S12.

\section{Results and discussion}

\subsection{Overview of retrieved factors}

The solution that best represented the input data was the eight-factor solution. The eight factors from the PMF results are as follows:

1. two firework factors with prominent relative contributions of $\mathrm{Bi}, \mathrm{Ba}, \mathrm{K}, \mathrm{S}, \mathrm{Ti}, \mathrm{Cu}$ and $\mathrm{Cl}$, which are important components of fireworks (Kong et al., 2015; Vecchi et al., 2008); 


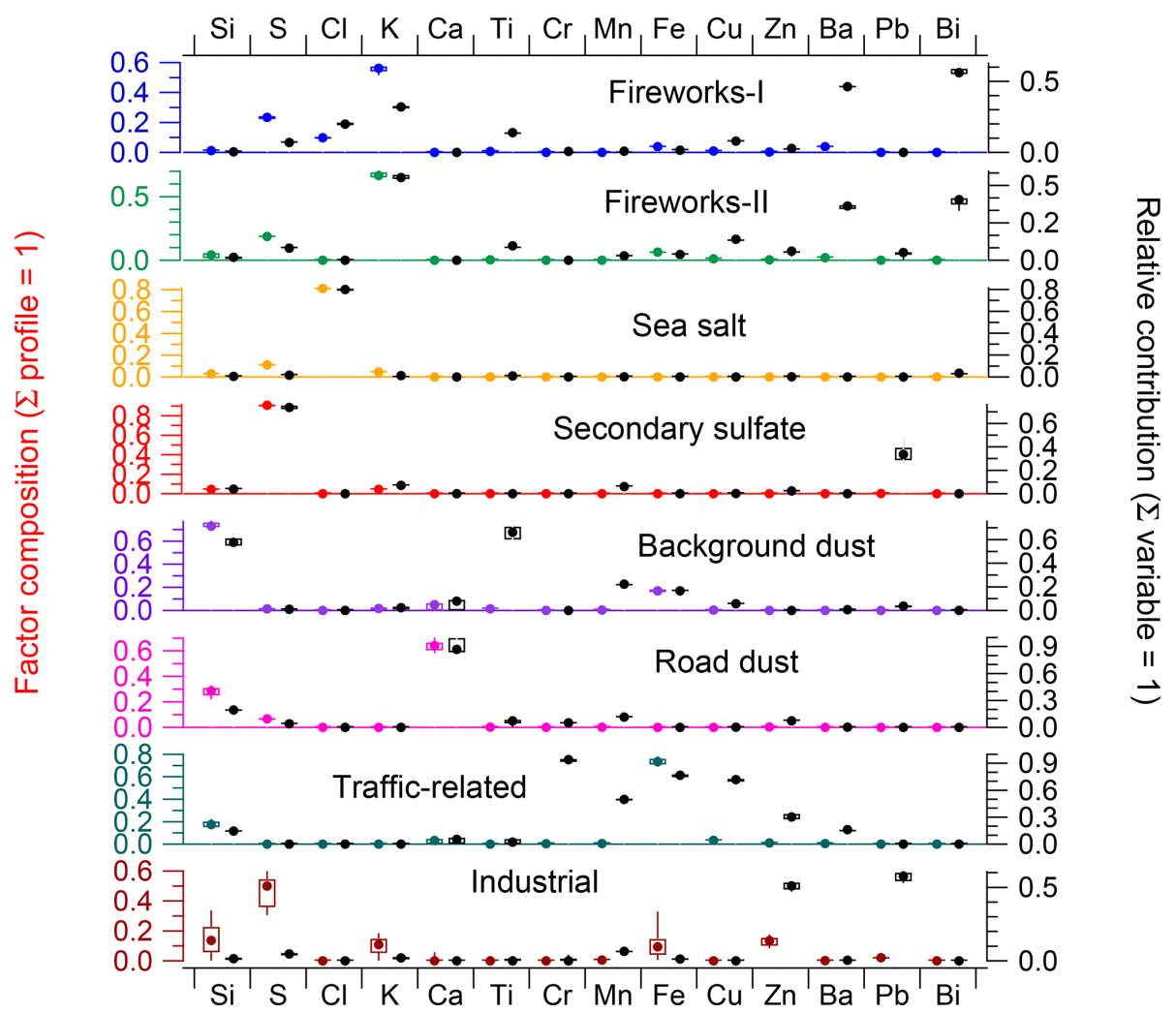

Figure 2. Source profiles of the finally retained eight-factor PMF results. The data and their corresponding uncertainty are given as boxwhisker plot (bottom to top: p10-p25-p50-p75-p90) of good solutions from bootstrap runs. The left $y$ axis represents the fractional composition of the factor profile row-wise (presented in coloured box-whisker plot) for each factor (in ng ng ${ }^{-1}$ ); the right $y$ axis represents the relative contribution of each factor to each variable (indicated in black box-whisker plot).

(a)

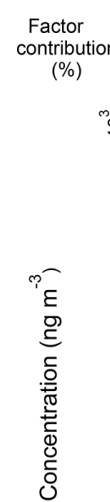

(a) \%)

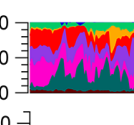

울 40 年
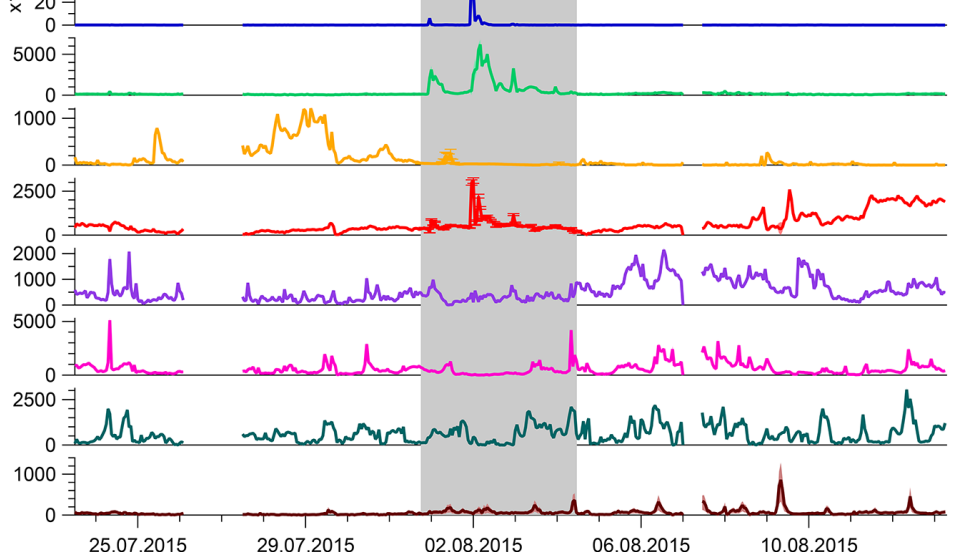

(b) Average concentration $3134\left(\mathrm{ng} \mathrm{m}^{-3}\right)$

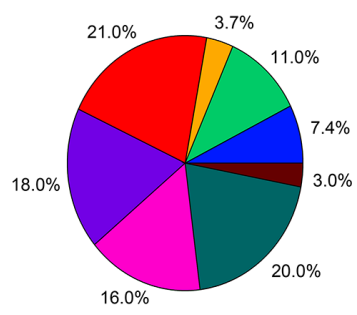

Fireworks-I

Fireworks-II

- Sea salt

- Secondary sulfate

- Background dust

- Road dust

- Non-exhaust traffic-related

- Industrial

Figure 3. (a) Time series of the $\mathrm{PM}_{10 \mathrm{el}}$ sources and relative contributions of the different sources over time. Shaded areas indicate the uncertainties (interquartiles) of selected bootstrap runs; grey background colour represents the firework period. The estimated uncertainties of the secondary sulfate $( \pm 5 \%)$ and the sea salt factors $( \pm 42 \%)$ during the firework period are added as error bars (magnified version is shown in Fig. S12). (b) Mean relative contributions of $\mathrm{PM}_{10 \mathrm{el}}$ sources. The average concentration represents the mean value of apportioned sources in $\mathrm{PM}_{10 \mathrm{el}}$, which is the sum of 14 elements. 
2. a sea salt factor explaining a large fraction of $\mathrm{Cl}$ in the $\mathrm{PM}_{10 \mathrm{el}}$ fraction;

3. a secondary sulfate factor mostly dominated by $\mathrm{S}$ and highly correlated with ACSM sulfate (Fig. S1);

4. two dust factors, one dominated by $\mathrm{Ca}$ and showing traffic rush hours peaks and the other dominated by $\mathrm{Si}$ without a clear diurnal pattern;

5. a non-exhaust traffic-related factor characterised by $\mathrm{Fe}$, $\mathrm{Cr}, \mathrm{Cu}, \mathrm{Mn}, \mathrm{Zn}$ and $\mathrm{Ba}$;

6. an industrial factor showing relatively high contributions of $\mathrm{Pb}$ and $\mathrm{Zn}$.

\subsection{Detailed factor description}

In this section, the results of the $\mathrm{PM}_{10 \mathrm{el}}$ mass driven by the sum of 14 elements are presented and validated. Figure 2 represents the fractional composition of the factor profile $\left(f_{k j} / \sum_{j} f_{k j}\right.$; left $y$ axis; coloured boxwhisker plots for each factor) and relative contribution $\left(\sum_{i} g_{i k} f_{k j} / \sum_{k} \sum_{i} g_{i k} f_{k j}\right.$ ) of each factor to each variable (right $y$ axis; black box-whisker plots). Figure 3 a shows the time series of the factor contributions (in $\mathrm{ng} \mathrm{m}^{-3}$; bottom panels) and of the relative contributions (top panel) of the retrieved $\mathrm{PM}_{10 \mathrm{el}}$ factors. The variability in these time series across all good solutions was relatively low. Figure $3 \mathrm{~b}$ reports the averaged total $\mathrm{PM}_{10 \mathrm{el}}$ mass and relative contributions of the $\mathrm{PM}_{10 \mathrm{el}}$ sources. The reported variabilities or uncertainties (which correspond to the interquartile range among selected bootstrap runs) are an indication of the high stability of the solution. The diurnal variations of the absolute concentrations of the identified factors and some of their corresponding external tracers are presented in Fig. 4. CBPF analysis was performed at the 90th percentile (Fig. 5) as well as at different percentile ranges (Fig. S13) to validate some of the identified sources and their characterisation.

Fireworks. The firework factor profiles and time series are shown in Figs. 2 and 3a respectively. The firework factors are mostly dominated by $\mathrm{K}, \mathrm{S}, \mathrm{Cl}, \mathrm{Ti}, \mathrm{Cu}, \mathrm{Ba}$ and $\mathrm{Bi}$, which are the chemical elemental species of fireworks (Moreno et al., 2007; Wang et al., 2007; Vecchi et al., 2008; Perrino et al., 2011; Tian et al., 2014; Kong et al., 2015; Lin, 2016; Pongpiachan et al., 2018). Ba and $\mathrm{Cu}$ compounds are used to produce green and blue fireworks. The presence of $\mathrm{Cl}$ in Fireworks-I suggests that the chloride salt might be the main chemical form in the fireworks, such as barium chloride. $\mathrm{K}$ is one of the major components of fireworks, which contains $74 \%$ of $\mathrm{KNO}_{3}$ in black powder as the oxidising agent for the burning process (Drewnick et al., 2006). The ACSM inorganic concentrations during the firework episodes indicate that neither particulate nitrate nor ammonium is generated in the fireworks in significant amounts (Fig. S14). Consistent with previous measurements of submicron firework aerosol (Drewnick et al., 2006; Vecchi et al., 2008; Jiang et al., 2015), nitrate was not enhanced during the firework period, suggesting conversion of $\mathrm{KNO}_{3}$ to other forms of nitrogen. The $\mathrm{NO}_{2} / \mathrm{K}$ mass ratio (1.66) in the main firework hour (1 August at 23:00 LT; see Fig. S14) is close to the molecular/atomic ratio of $\mathrm{NO}_{2} / \mathrm{K}(1.17)$. This measured ratio is also in agreement with the $\mathrm{NO}_{2} / \mathrm{K}^{+}(2.03)$ ratio observed during the Chinese Spring Festival in Shanghai (Yao et al., 2019). However, the $\mathrm{NO}_{2}$ and $\mathrm{NO}_{x}$ variation was not significant during the firework peaks in the present study (Fig. S14), which is in agreement with the former studies (Vecchi et al., 2008; Retama et al., 2019; Yao et al., 2019). The K/S ratio of 2.72 in the Fireworks-I factor profile is in good agreement with the $\mathrm{K} / \mathrm{S}$ elemental concentration ratio $(\sim 2.76)$ in black powder (Dutcher et al., 1999). Other $\mathrm{K}$ compounds in black powder can be in the form of perchlorate or chlorate (Wang et al., 2007). Bi is used in crackling stars (dragon's eggs) in the form of bismuth trioxide or subcarbonate as a non-toxic substitute for toxic lead compounds (Perrino et al., 2011). The $\mathrm{Ba} / \mathrm{K}$ ratio of $0.031-0.054$ for Fireworks-I and Fireworks-II is close to the value 0.057 reported in Pongpiachan et al. (2018). Firework particles are usually present in large amounts in the fine fraction, staying longer in the atmosphere (Richard et al., 2011; Moreno et al., 2007). A pronounced increase in both firework factor time series is observed when the fireworks traditionally begin. The diurnal patterns of the firework-related elements exhibit a peak at 23:00 LT during the firework period (Furger et al., 2017) in accordance with the Fireworks-I diurnal variation (Fig. 4c). Both firework factors contain two sharp peaks. The Fireworks-I factor concentration started to increase on 31 July 2015 at 22:00 LT and formed the extreme peak within $1 \mathrm{~h}$ at 23:00 LT $\left(\sim 5 \mu \mathrm{g} \mathrm{m}^{-3}\right)$. After that it decayed quickly (10 times lower concentration than maximum firework concentration) within $1 \mathrm{~h}$ and remained more or less constant until 1 August 2015 at 21:00 LT. It again started to increase at 22:00 LT and formed a second sharp peak on 1 August 2015 at 23:00 LT, followed by a gradual decay over the next 6 to $10 \mathrm{~h}$. Fireworks-II presents a slightly different pattern in its time series. It started to increase on 31 July 2015 at 22:00 LT and depicted its highest peak at 00:00 LT $\left(\sim 3.6 \mu \mathrm{g} \mathrm{m}^{-3}\right)$, with quite a slow decay until 1 August 2015 at 06:00 LT. The concentration remained slightly higher than Fireworks-I over daytime. It then started to increase again from 1 August 2015 at 17:00 LT and yielded the highest peak on 2 August 04:00 LT, with $6.7 \mu \mathrm{g} \mathrm{m}^{-3}$. It remained higher until 2 August 2015 at 08:00 LT and slowly decayed until the afternoon, followed by further prominent peaks at 23:00 LT on 2 and $3 \mathrm{Au}-$ gust. Chemical reactions of $\mathrm{KCl}$ with $\mathrm{H}_{2} \mathrm{SO}_{4}$ will result in a release of gaseous $\mathrm{HCl}$ and may explain the absence of particulate $\mathrm{Cl}$ in the Fireworks-II factor profile. The time series variations in both fireworks suggest that Fireworks-I might be related to the main firework celebration, while FireworksII might result from burning of leftover crackers after the main firework day as well as the influence of other sources such as bonfires, which are a common activity during Swiss 

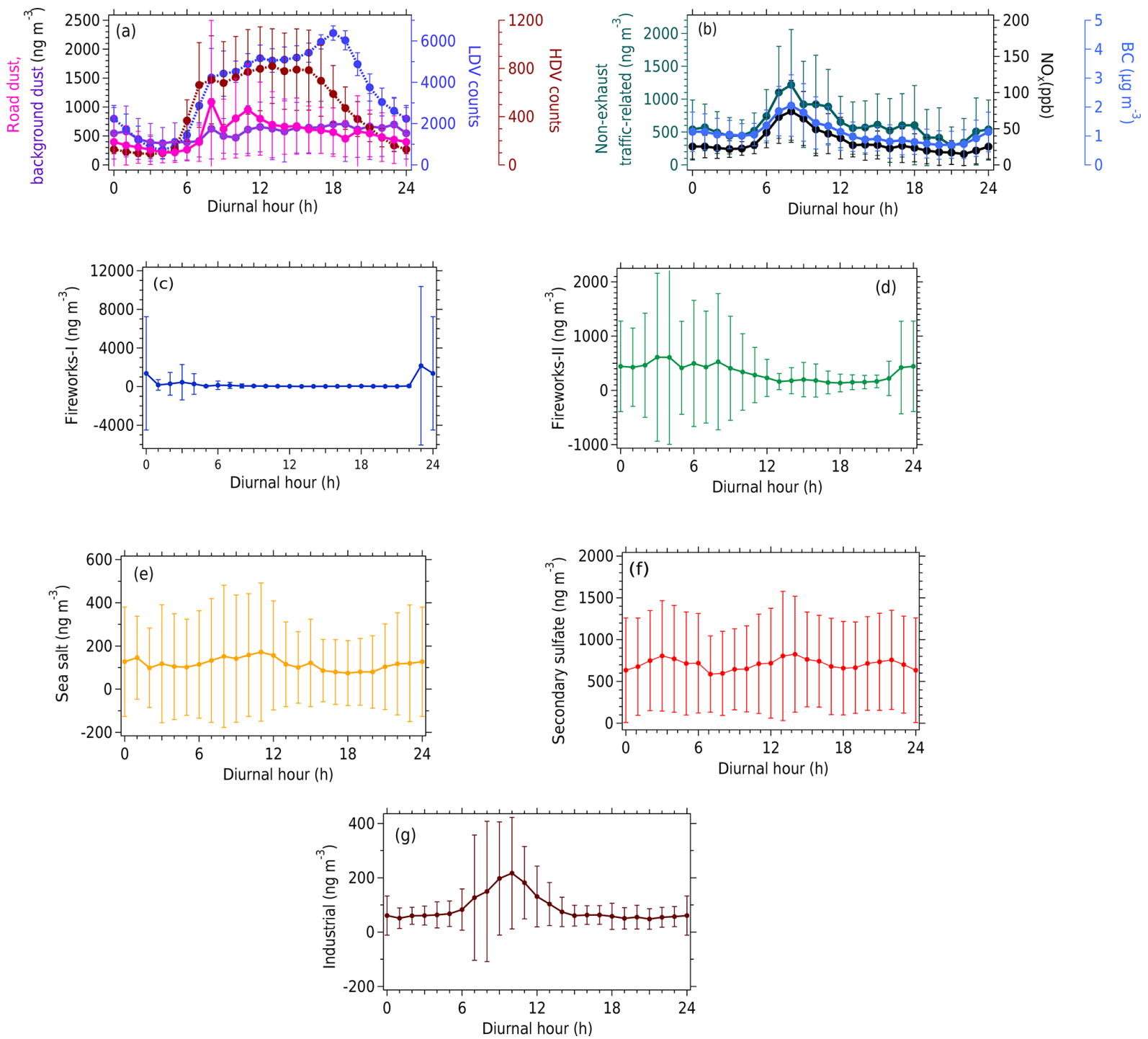

Figure 4. Mean diurnal patterns of the factors and of some corresponding external tracers with error bars (1 standard deviation).

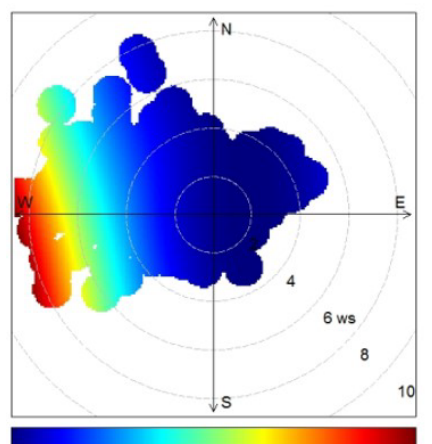

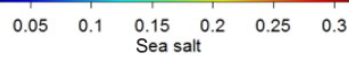

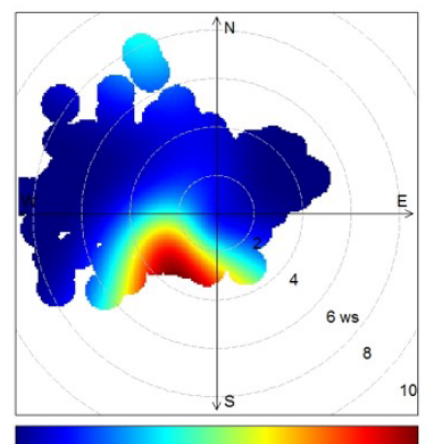

$0.02 \quad \begin{array}{ccc}0.04 & 0.06 & 0.08 \\ \text { Background dust } & 0.1\end{array}$

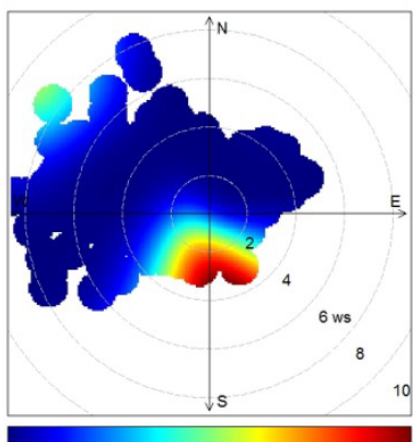

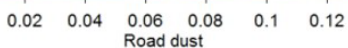

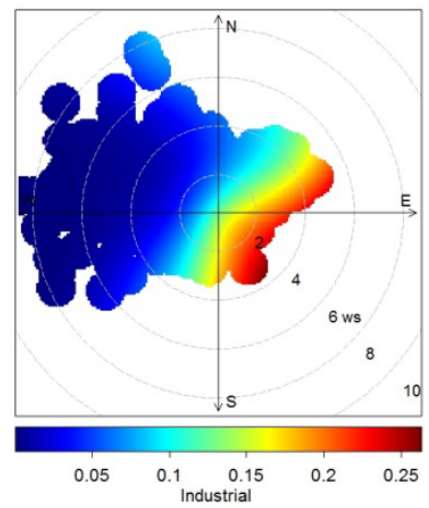

Figure 5. CBPF analysis (at 90th percentile) of factors in terms of wind speed $\left(\mathrm{m} \mathrm{s}^{-1}\right)$ and wind direction. The colour code represents the probability of the factor contribution. 
National Day celebrations. Another possibility could be the advection of firework clouds from nearby cities, where grand firework displays and bonfires are carried out at a large scale to celebrate the Swiss National Day. The average relative contributions of Fireworks-I and Fireworks-II to the analysed mass were $7.4 \%$ and $11 \%$ respectively (Fig. 3b). Figure S15 represents an estimate of overall firework composition and temporal variability, complementing the PMF results. A K concentration $>220 \mathrm{ng} \mathrm{m}^{-3}$ was used as the criterion to separate firework data points (65 data points) from the whole dataset. The detailed description is mentioned in the Supplement. Most of the elements are well captured by two firework factors, such as $\mathrm{S}, \mathrm{K}, \mathrm{Fe}, \mathrm{Cu}, \mathrm{Ba}$, etc., since they lie within the firework data distribution. In contrast, there are some elements that do not contribute to fireworks, e.g. $\mathrm{Ca}$ and $\mathrm{Cr}$, while some elements are explained by only one firework, e.g. $\mathrm{Si}, \mathrm{Cl}$ and $\mathrm{Pb}$. This indicates that a single firework factor is not enough to represent the firework data variability.

Sea salt. The sea salt factor was mainly composed of $\mathrm{Cl}$ ( $81 \%$ of the factor mass) as shown in the factor profile (Fig. 2), with no diurnal pattern (Fig. 4e). The average relative contribution of the sea salt factor to the analysed mass was $3.7 \%$ (Fig. 3b). Sea salt also includes $\mathrm{Na}$ and $\mathrm{Mg}$, which were not measured by the Xact but analysed by ICP-OES for $24 \mathrm{~h}$ offline filters. Based on the high correlation of $\mathrm{Na}$ and $\mathrm{Cl}$ in a previous study, $\mathrm{Cl}$ alone can be used as a marker for sea salt particles (Vallius, 2005). The existence of sea salt particles was confirmed by a low $\mathrm{Mg} / \mathrm{Na}$ ratio in the filter data, equalling 0.13 and 0.16 for 28 and 30 July, respectively, in line with a ratio of 0.132 to 0.185 for marine aerosol (Chesselet et al., 1972). For the remaining eight filter samples, $\mathrm{Mg} / \mathrm{Na}$ was higher than 0.18 , probably due to absence of sea salt (Fig. S16). A comparison with ACSM data revealed that $\mathrm{Cl}$ was mainly present in the fine fraction $\left(\mathrm{PM}_{1}\right)$ during firework days, while during the rest of the campaign it was in $\mathrm{PM}_{10}$ (Fig. S17). The measured $\mathrm{Cl} / \mathrm{Ca}$ ratio (0.33) from Xact does not lie in the range of de-icing salt composition (5.27) measured in northern Germany (Pernigotti et al., 2016), which validates our interpretation as a sea salt factor. In addition, the highest $\mathrm{Cl}$ concentrations were observed only in the last week of July, with westerly winds at higher wind speeds (5-8 $\mathrm{m} \mathrm{s}^{-1}$; Figs. S17 and S18). This result is in agreement with the CBPF plot, where the high concentration of the sea salt factor dominates for westerly winds with high wind speeds (Figs. 5 and S13) and confirms previous studies (Visser et al., 2015; Twigg et al., 2015).

Dust. The PMF analysis resolved two dust-related factors, i.e. a road dust (Ca-rich) and a background dust (Si-rich) factor, with average relative contributions to the analysed mass of $18 \%$ and $16 \%$, respectively (Fig. 3b). The road dust factor was mainly composed of $\mathrm{Ca}$ (68\% of the factor mass) followed by $\mathrm{Si}(26 \%)$, with relative contributions of $89 \%$ to $\mathrm{Ca}, 19 \%$ to $\mathrm{Si}$ and $12 \%$ to $\mathrm{Mn}$, while the background dust factor highly contributed to $\mathrm{Ti}, \mathrm{Si}, \mathrm{Mn}, \mathrm{Fe}$ and $\mathrm{Ca}$, with $65 \%$, $58 \%, 22 \%, 16 \%$ and $6 \%$, respectively. The two dust factors together explain $95 \%$ of $\mathrm{Ca}$, while the remaining factors explain only $5 \%$ of $\mathrm{Ca}$. The solution with two dust factors resulted in reduced scaled residuals for $\mathrm{Si}$ and $\mathrm{Ca}$ compared to a solution with one dust factor (Fig. S19). The scatter plot of the absolute concentrations of $\mathrm{Si}$ and $\mathrm{Ca}$ also indicates the presence of two different sources (Fig. S20). The high relative contribution of $\mathrm{Ca}$ in road dust has also been found in other source apportionment studies (Ducret-Stich et al., 2013; Bukowiecki et al., 2010). In general, $\mathrm{Ca}$ and $\mathrm{Si}$ are commonly associated with mineral dust, construction activities, vehicular emissions, and iron and steel plants (Lee and Pacyna, 1999; Vega et al., 2001; Bukowiecki et al., 2010; Crilley et al., 2016; Maenhaut, 2017). Iron and steel plants produce furnace slacks, a glass-like by-product which consists of $\mathrm{Ca}, \mathrm{Si}, \mathrm{Mg}$ and $\mathrm{Al}$ oxides. The higher fraction of crustal elements such as $\mathrm{Ca}$ and $\mathrm{Si}$ in road dust might be a consequence of the widespread use of asphalt and concrete to make roads (Fullova et al., 2017; Li et al., 2004). The sampling site is located close to the freeway and must be influenced by wear and tear of the asphalt and concrete roads because of heavy traffic. Ca has been associated with construction activities in previous studies (Bernardoni et al., 2011; Crilley et al., 2016), which have been found to peak during the day and decrease to almost zero outside of normal working times (08:00 until 17:00 LT). This evidence is not supported by the road or background dust factor diurnal pattern in this study. Further evidence of non-construction activity is found in the Xact elemental ratio of $\mathrm{Ca} / \mathrm{S}(0.62)$, which is not in agreement with the pure gypsum $\mathrm{Ca} / \mathrm{S}$ ratio (1.25) used for construction work (Hassan et al., 2014), where the two elements are the main constituents. Road dust profiles are often difficult to identify due to resuspension of materials deposited on the road surface such as mineral dust, vehicle wear and tear, and/or road surface wear and tear. However, the road dust factor profile is distinct from the non-exhaust traffic-related factor profile. It is possible that the road dust factor is related to resuspension of mineral dust and road wear and tear particles. The high contribution of $\mathrm{Ca}$ alone ( $>80 \%$ ) has been seen in previous studies (Ducret-Stich et al., 2013; Bukowiecki et al., 2010; Hueglin et al., 2005), where it was named "road dust". Another study at a rural site in Switzerland also found the Ca-rich factor in the coarse fraction, where it was linked to soil resuspension (Minguillón et al., 2012). The background dust factor profile exhibits elements associated with mineral dust, such as $\mathrm{Ti}, \mathrm{Si}$ and $\mathrm{Fe}$. These and other terrestrial elements are commonly present in soil as oxides (Rudnick and Gao, 2003). The background dust factor also contains a significant fraction of the measured $\mathrm{Mn}$, which is one of the most abundant compounds in the earth's crust, where it occurs in the form of $\mathrm{MnO}_{2}$ (Taylor and McLennan, 1995). Since the sampling site is adjacent to agricultural fields in the northern and western directions, the contribution of these elements to this factor can be expected. A similar background factor with high contributions of $\mathrm{Si}$, Ti 
and Ca was found by Richard et al. (2011) at an urban site in Switzerland.

The separation of two dust factors is in line with Amato et al. (2009), where ME-2 yielded a road dust factor distinct from a mineral dust factor. The CBPF plot shows that higher concentrations of the road dust factor are associated with the southern wind sector, while the background dust factor is influenced by the south-western and north-eastern wind sectors (Figs. 5, S12). The diurnal pattern of the road dust factor shows morning rush hour traffic peaks similar to the $\mathrm{NO}_{x}, \mathrm{BC}$ and HDV count and non-exhaust traffic-related factor (Figs. 4a and b), indicating that the resuspension of road dust is due to the vehicle fleet. A similar relationship between road dust and the non-exhaust traffic-related source was observed in a previous study (Amato et al., 2009). Resuspension of road dust in the early morning traffic is not triggered by wind speed (Fig. S21) but by the traffic fleet, whereas in the afternoon, an increase in wind speed leads to resuspension of dust deposited on the road as well as resuspension of agricultural soil dust near the sampling site. Therefore, meteorology plays a vital role for the contribution of the background dust factor.

Non-exhaust traffic-related. The non-exhaust trafficrelated factor profile was mostly dominated by $\mathrm{Fe}(73 \%$ of the factor mass) and contributed strongly to $\mathrm{Cr}(96 \%), \mathrm{Fe}$ (76\%), Cu (71\%), Mn (50\%), Zn (31\%), Ba (26\%) and $\mathrm{Si}(12 \%)$. Its average relative contribution to the analysed mass was $20 \%$ (Fig. 3b). Coarse particles from brake or disc wear could appear as flakes and mainly consist of iron oxides (Wahlström et al., 2010). The higher fraction of Fe in the non-exhaust traffic-related source has been found in several previous studies (Visser et al., 2015; Amato et al., 2014a; Bukowiecki et al., 2010; Dall'Osto et al., 2013; Crilley et al., 2016). However, the ratio of Fe to other elements is variable between studies. $\mathrm{Fe}, \mathrm{Cr}, \mathrm{Cu}, \mathrm{Zn}, \mathrm{Mn}$ and $\mathrm{Ba}$ are the most abundant trace elements in brake pads and brake lining and thus attributed to tire or brake wear (Thorpe and Harrison, 2008; Grigoratos and Martini, 2015; Gianini et al., 2012) and engine wear. $\mathrm{Si}$ is one of the brake lining components used as an abrasive to increase friction and as fillers to reduce manufacturing costs (Thorpe and Harrison, 2008; Grigoratos and Martini, 2015). This factor is characterised by a strong diurnal peak coinciding with the morning rush hour at 08:00 LT, similar to $\mathrm{NO}_{x}$ and $\mathrm{BC}$ (Fig. 4b). The LDV and HDV counts start to increase at 05:00 LT (Fig. 4a), unlike the primary traffic emission $\mathrm{NO}_{x}$ and $\mathrm{BC}$. The similar diurnal pattern of this factor might be due to the high braking load for vehicles during peak traffic hours, resulting in increased emissions of vehicle wear particles.

Secondary sulfate. This source is characterised by sulfur (S) and is most likely due to the regional background contribution of secondary sulfate due to conversion of $\mathrm{SO}_{2}$ to $\mathrm{SO}_{4}^{2-}$, consistent with the results of many previous source apportionment studies (Dall'Osto et al., 2013; Richard et al., 2011). It explains the highest fraction of $\mathrm{S}(91 \%$ of the factor mass) with relative contributions to $\mathrm{S}(73 \%)$ and $\mathrm{Pb}$ (30\%; Fig. 2). The average relative contribution of this factor to the analysed mass is $21 \%$ (Fig. 3b). Similar factor profiles were found in previous studies (Visser et al., 2015; Dall'Osto et al., 2013). This factor correlates well with ACSM SO 4 measurements $\left(r^{2}=0.91\right)$, suggesting a dominant contribution from the submicron fraction and thus a slow rate of dry deposition. Combined with $\mathrm{SO}_{2}$ oxidation processes occurring on timescales of hours to days, it is thus reasonable that the secondary sulfate factor does not exhibit a clear diurnal variation (Fig. 4f) and is consistent with regional rather than local sources. The time series of secondary sulfate exhibits peaks during the firework event (Fig. 3a), in agreement with the ACSM SO $\mathrm{AC}_{4}^{2-}$ time series (Fig. S22). Inorganic gases $\left(\mathrm{SO}_{2}, \mathrm{NO}_{x}\right.$, etc.) emitted during the firework events may be oxidised to secondary organic and inorganic components that may condense to the particle phase (Sarkar et al., 2010) within a very short span of time, as observed in previous studies (Wang et al., 2007; Yang et al., 2014). We monitored two parameters to explain the influence of fireworks in the secondary sulfate time series: (1) mass balance for ACSM PM data and (2) secondary sulfate peaks during the main firework hours (1 August from 23:00 LT to midnight). The equivalent concentration of ammonium $\left(\mathrm{NH}_{4 \mathrm{eq}}\right)$ balances the sum of $\mathrm{NH}_{4 \text { eq }}$ and $\mathrm{SO}_{4 \text { eq }}$ during non-firework periods, while during firework peaks, the balance shifts towards the sum of $\mathrm{NH}_{4 \mathrm{eq}}$ and $\mathrm{SO}_{4 \text { eq }}$ (Fig. S23). This indicates that sulfate related to fireworks adds up to an acidic budget of particles. The excess sulfate observed from this analysis is approximately in quantitative agreement (within $20 \%$ ) with the enhancement of the secondary sulfate during the firework period. The peak in the secondary sulfate observed at 23:00 LT on 1 August is slightly offset from the main firework peak because the secondary sulfate formed maximum peaks $1 \mathrm{~h}$ later (00:00 LT on 2 August). Taking these two together suggests that we may have some downstream production of sulfuric acid and conversion to ammonium sulfate, which makes the secondary sulfate factor time series slightly delayed relative to the main firework plume. Because this delay is consistent with chemical processing, we consider inclusion of this temporal feature in the secondary sulfate factor to be reasonable, although we cannot completely rule out some degree of mathematical mixing with the direct firework emissions. The time series of $\mathrm{ACSM} \mathrm{SO}_{4}^{2-}$ and $\mathrm{ACSM} \mathrm{NH}+$ show significant correlation (Fig. S22), indicating the formation of ammonium sulfate particles except for the main firework peaks.

Industrial. This factor is characterised by high relative contributions to $\mathrm{Zn}(50 \%)$ and $\mathrm{Pb}(63 \%)$, with a low contribution to the analysed mass (on the order of $3 \%$; Fig. $3 b$ ). The profile is shown in Fig. 2 and the time series in Fig. 3a. The time series contains a few spikes after 4 August, when the wind was predominantly from the southern and southeastern sector, suggesting an industrial emission. A similar factor profile was observed in previous source apportionment studies (Crilley et al., 2016; Richard et al., 2011) from local 
point source emissions without any link to specific industrial activities. Industrial emissions play a minor role in this study area, as it is surrounded by only a few small-scale industrial buildings (logistics businesses approximately $500 \mathrm{~m}$ to the north-west and a wheel manufacturing company to the southeast, across the freeway). The CBPF plot confirms the dominance of high concentrations in the south-eastern direction (Fig. 5). The diurnal cycle shows a clear peak at 10:00 LT (Fig. $4 \mathrm{~g}$ ) which is related to a few peaks.

\section{Conclusion}

A source apportionment study of 14 elements in $\mathrm{PM}_{10}$ measured at a traffic-influenced site in Härkingen, Switzerland, during the summer of 2015 was conducted using the ME-2 implementation of PMF. The PMF model was able to resolve and evaluate the contributions and compositions of eight sources: two firework factors, sea salt, secondary sulfate, background dust, road dust, a non-exhaust traffic-related factor and an industrial source. The use of ME-2 allowed the use of constraints via the $a$-value approach, which improved the factor resolution relative to conventional PMF. We show that the rotational control available in ME- 2 provides a means for treating extreme events such as fireworks within a PMF analysis. This was only achievable when controlling problematic factors, i.e. factors that tend to mix within the constraining technique. Two dust factors with different time profiles and two firework factors were identified by the PMF model, resulting in better representation of the data variability. A Srich (secondary sulfate) factor, which can typically be attributed to regional background and transported secondary sulfate, was correlated with fine-mode non-refractory sulfate measured by an ACSM. The non-exhaust traffic-related factor followed the diurnal pattern of traffic rush hours similar to $\mathrm{NO}_{x}$ and $\mathrm{BC}$, with concentrations up to 4 times higher during daytime relative to night-time. The outcome of this study emphasises the significant influence of regional background secondary sulfate and local background dust apart from nonexhaust traffic emissions at the sampling location. The small contribution of the industrial factor confirms the low influence of local daily activities from the surroundings.

The source apportionment model performance could possibly be additionally improved by the inclusion of $\mathrm{Na}$ and $\mathrm{Sr}$ to better resolve the sea salt and firework factors, respectively. It was shown that high-time-resolution element datasets enable a fully resolved SA, with considerable improvements compared to $24 \mathrm{~h}$ filter analysis, where the attribution to specific sources is possible only on a larger timescale and is mostly based on seasonal variations.

Data availability. The datasets are available upon request to the corresponding author.
Supplement. The supplement related to this article is available online at: https://doi.org/10.5194/acp-20-1657-2020-supplement.

Author contributions. PR performed SA analysis and wrote the paper. MF, RF and $\mathrm{CH}$ performed the measurement. MF and RF analysed the data for Xact and ACSM, respectively. FC and JGS provided expertise on software for SA analysis. MCM provided ICPMS and ICP-AES analysis data. KP lent Xact 625 for measurement. UB, ASHP, MF, FC and JGS were involved with the supervision and conceptualisation. All authors commented on the paper and assisted in the interpretation of the results.

Competing interests. Krag Petterson is employed by Cooper Environmental Services, the manufacturer of Xact 625.

Acknowledgements. We thank René Richter and Roland Scheidegger of PSI for their technical support during the measurement campaign. We are grateful to Chris Koch and Varun Yadav of Cooper Environmental Services for instructions on the instrument and numerous technical discussions. We thank the operators of the NABEL station for providing all kinds of support during the measurements.

Financial support. This study has been funded by the Swiss Federal Office for the Environment (FOEN). This research has been supported by the Swiss National Science Foundation (SNSF; grant nos. 200021_162448/1 and BSSGI0_155846). María Cruz Minguillón acknowledges the Ramón y Cajal Fellowship awarded by the Spanish Ministry.

Review statement. This paper was edited by Willy Maenhaut and reviewed by four anonymous referees.

\section{References}

Amato, F., Pandolfi, M., Escrig, A., Querol, X., Alastuey, A., Pey, J., Perez, N., and Hopke, P. K.: Quantifying road dust resuspension in urban environment by Multilinear Engine: A comparison with PMF2, Atmos. Environ., 43, 2770-2780, https://doi.org/10.1016/j.atmosenv.2009.02.039, 2009.

Amato, F., Pandolfi, M., Moreno, T., Furger, M., Pey, J., Alastuey, A., Bukowiecki, N., Prevot, A. S. H., Baltensperger, U., and Querol, X.: Sources and variability of inhalable road dust particles in three European cities, Atmos. Environ., 45, 6777-6787, https://doi.org/10.1016/j.atmosenv.2011.06.003, 2011.

Amato, F., Alastuey, A., de la Rosa, J., Gonzalez Castanedo, Y., Sánchez de la Campa, A. M., Pandolfi, M., Lozano, A., Contreras González, J., and Querol, X.: Trends of road dust emissions contributions on ambient air particulate levels at rural, urban and industrial sites in southern Spain, Atmos. Chem. Phys., 14, 35333544, https://doi.org/10.5194/acp-14-3533-2014, 2014a. 
Amato, F., Cassee, F. R., Denier van der Gon, H. A. C., Gehrig, R., Gustafsson, M., Hafner, W., Harrison, R. M., Jozwicka, M., Kelly, F. J., Moreno, T., Prevot, A. S. H., Schaap, M., Sunyer, J., and Querol, X.: Urban air quality: The challenge of traffic non-exhaust emissions, J. Hazard. Mater., 275, 31-36, https://doi.org/10.1016/j.jhazmat.2014.04.053, 2014 b.

Ancelet, T., Davy, P. K., Mitchell, T., Trompetter, W. J., Markwitz, A., and Weatherburn, D. C.: Identification of particulate matter sources on an hourly time-scale in a wood burning community, Environ. Sci. Technol., 46, 4767-4774, https://doi.org/10.1021/es203937y, 2012.

Belis, C. A., Favez, O., Mircea, M., Diapouli, E., Manousakas, M.-I., Vratolis, S., Gilardoni, S., Paglione, M., Decesari, S., Mocnik, G., Mooibroek, D., Salvador, P., Takahama, S., Vecchi, R., and Paatero, P.: European guide on air pollution source apportionment with receptor models - Revised version 2019, JRC117306, EUR 29816 EN, Publications Office of the European Union, Luxembourg, 2019, ISBN 978-92-76-09001-4, https://doi.org/10.2760/439106, 2019a.

Belis, C. A., Pikridas, M., Lucarelli, F., Petralia, E., Cavalli, F., Calzolai, G., Berico, M., and Sciare, J.: Source apportionment of fine $\mathrm{PM}$ by combining high time resolution organic and inorganic chemical composition datasets, Atmos, Environ.: X, 3, 100046, https://doi.org/10.1016/j.aeaoa.2019.100046, 2019 b.

Bernardoni, V., Vecchi, R., Valli, G., Piazzalunga, A., and Fermo, P.: PM $_{10}$ source apportionment in Milan (Italy) using time-resolved data, Sci. Total Environ., 409, 4788-4795, https://doi.org/10.1016/j.scitotenv.2011.07.048, 2011.

Bozzetti, C., Daellenbach, K. R., Hueglin, C., Fermo, P., Sciare, J., Kasper-Giebl, A., Mazar, Y., Abbaszade, G., El Kazzi, M., Gonzalez, R., Shuster-Meiseles, T., Flasch, M., Wolf, R., Křepelová, A., Canonaco, F., Schnelle-Kreis, J., Slowik, J. G., Zimmermann, R., Rudich, Y., Baltensperger, U., El Haddad, I., and Prévôt, A. S. H.: Size-resolved identification, characterization, and quantification of primary biological organic aerosol at a European rural site, Environ. Sci. Technol., 50, 3425-3434, https://doi.org/10.1021/acs.est.5b05960, 2016.

Brauer, M., Hoek, G., Vliet, P. V., Meliefste, K., Fischer, P. H., Wijga, A., Koopman, L. P., Neijens, H. J., Gerritsen, J., Kerkhof, M., Heinrich, J., Bellander, T., and Brunekreef, B.: Air pollution from traffic and the development of respiratory infections and asthmatic and allergic symptoms in children, Am. J. Resp. Crit. Care, 166, 1092-1098, https://doi.org/10.1164/rccm.200108-007OC, 2002.

Bukowiecki, N., Lienemann, P., Zwicky, C. N., Furger, M., Richard, A., Falkenberg, G., Rickers, K., Grolimund, D., Borca, C., Hill, M., Gehrig, R., and Baltensperger, U.: X-ray fluorescence spectrometry for high throughput analysis of atmospheric aerosol samples: The benefits of synchrotron X-rays, Spectrochim. Acta B, 63, 929-938, https://doi.org/10.1016/j.sab.2008.05.006, 2008.

Bukowiecki, N., Lienemann, P., Hill, M., Figi, R., Richard, A., Furger, M., Rickers, K., Falkenberg, G., Zhao, Y., Cliff, S. S., Prévôt, A. S. H., Baltensperger, U., Buchmann, B., and Gehrig, R.: Real-world emission factors for antimony and other brake wear related trace elements: size-segregated values for light and heavy duty vehicles, Environ. Sci. Technol., 43, 8072-8078, https://doi.org/10.1021/es9006096, 2009.
Bukowiecki, N., Lienemann, P., Hill, M., Furger, M., Richard, A., Amato, F., Prévôt, A. S. H., Baltensperger, U., Buchmann, B., and Gehrig, R.: PM $_{10}$ emission factors for non-exhaust particles generated by road traffic in an urban street canyon and along a freeway in Switzerland, Atmos. Environ., 44, 2330 2340, https://doi.org/10.1016/j.atmosenv.2010.03.039, 2010.

Cakmak, S., Dales, R., Kauri, L. M., Mahmud, M., Ryswyk, K. V., Vanos, J., Liu, L., Kumarathasan, P., Thomson, E., Vincent, R., and Weichenthal, S.: Metal composition of fine particulate air pollution and acute changes in cardiorespiratory physiology, Environ. Pollut., 189, 208-214, https://doi.org/10.1016/j.envpol.2014.03.004, 2014.

Canonaco, F., Crippa, M., Slowik, J. G., Baltensperger, U., and Prévôt, A. S. H.: SoFi, an IGOR-based interface for the efficient use of the generalized multilinear engine (ME2) for the source apportionment: ME-2 application to aerosol mass spectrometer data, Atmos. Meas. Tech., 6, 3649-3661, https://doi.org/10.5194/amt-6-3649-2013, 2013.

Carslaw, D. C. and Beevers, S. D.: Characterising and understanding emission sources using bivariate polar plots and k-means clustering, Environ. Modell. Softw., 40, 325-329, https://doi.org/10.1016/j.envsoft.2012.09.005, 2013.

Cesari, D., Genga, A., Ielpo, P., Siciliano, M., Mascolo, G., Grasso, F. M., and Contini, D.: Source apportionment of $\mathrm{PM}_{2.5}$ in the harbour-industrial area of Brindisi (Italy) Identification and estimation of the contribution of inport ship emissions, Sci. Total Environ., 497-498, 392-400, https://doi.org/10.1016/j.scitotenv.2014.08.007, 2014.

Chan, D. and Stachowiak, G. W.: Review of automotive brake friction materials, P. I. Mech. Eng. D-J. Aut., 218, 953-966, https://doi.org/10.1243/0954407041856773, 2004.

Chang, Y., Huang, K., Xie, M., Deng, C., Zou, Z., Liu, S., and Zhang, Y.: First long-term and near real-time measurement of trace elements in China's urban atmosphere: temporal variability, source apportionment and precipitation effect, Atmos. Chem. Phys., 18, 11793-11812, 10.5194/acp-18-11793-2018, 2018.

Chesselet, R., Morelli, J., and Buat-Menard, P.: Variations in ionic ratios between reference sea water and marine aerosols, J. Geophys. Res., 77, 5116-5131, https://doi.org/10.1029/JC077i027p05116, 1972.

Cooper, J. A., Petterson, K., Geiger, A., Siemers, A., and Rupprecht, B.: Guide for developing a multi-metals, fenceline monitoring plan for fugitive emissions using X-ray based monitors, Cooper Environmental Services, Portland, Oregon, 1-42, 2010.

Crenn, V., Sciare, J., Croteau, P. L., Verlhac, S., Fröhlich, R., Belis, C. A., Aas, W., Äijälä, M., Alastuey, A., Artiñano, B., Baisnée, D., Bonnaire, N., Bressi, M., Canagaratna, M., Canonaco, F., Carbone, C., Cavalli, F., Coz, E., Cubison, M. J., Esser-Gietl, J. K., Green, D. C., Gros, V., Heikkinen, L., Herrmann, H., Lunder, C., Minguillón, M. C., Močnik, G., O’Dowd, C. D., Ovadnevaite, J., Petit, J.-E., Petralia, E., Poulain, L., Priestman, M., Riffault, V., Ripoll, A., Sarda-Estève, R., Slowik, J. G., Setyan, A., Wiedensohler, A., Baltensperger, U., Prévôt, A. S. H., Jayne, J. T., and Favez, O.: ACTRIS ACSM intercomparison - Part 1: Reproducibility of concentration and fragment results from 13 individual Quadrupole Aerosol Chemical Speciation Monitors (Q-ACSM) and consistency with co-located instruments, Atmos. Meas. Tech., 8, 5063-5087, https://doi.org/10.5194/amt-8-50632015, 2015. 
Crilley, L. R., Lucarelli, F., Bloss, W. J., Harrison, R. M., Beddows, D. C., Calzolai, G., Nava, S., Valli, G., Bernardoni, V., and Vecchi, R.: Source apportionment of fine and coarse particles at a roadside and urban background site in London during the 2012 summer ClearfLo campaign, Environ. Pollut., 220, 766-778, https://doi.org/10.1016/j.envpol.2016.06.002, 2016.

Cui, Y., Ji, D., Chen, H., Gao., M., Maenhaut, W., He, J., and Wang, Y.: Characteristics and sources of hourly trace elements in airborne fine particles in urban Beijing, China, J. Geophys. Res.-Atmos., 124, 11595-11613, https://doi.org/10.1029/2019JD030881, 2019.

Dall'Osto, M., Querol, X., Amato, F., Karanasiou, A., Lucarelli, F., Nava, S., Calzolai, G., and Chiari, M.: Hourly elemental concentrations in $\mathrm{PM}_{2.5}$ aerosols sampled simultaneously at urban background and road site during SAPUSS - diurnal variations and PMF receptor modelling, Atmos. Chem. Phys., 13, 43754392, https://doi.org/10.5194/acp-13-4375-2013, 2013.

Dao, L., Morrison, L., and Zhang, C.: Bonfires as a potential source of metal pollutants in urban soils, Galway, Ireland, Appl. Geochem., 27, 930-935, https://doi.org/10.1016/j.apgeochem.2012.01.010, 2012.

Dockery, D. W., Pope III, C. A., Xu, X., Spengler, J. D., Ware, J. H., Fay, M. E., Ferris, B. G., and Speizer, F. E.: An association between air pollution and mortality in six U.S. cities, New Engl. J. Med., 329, 1753-1759, https://doi.org/10.1056/NEJM199312093292401, 1993.

Drewnick, F., Hings, S. S., Curtius, J., Eerdekens, G., and Williams, J.: Measurement of fine particulate and gasphase species during the New Year's fireworks 2005 in Mainz, Germany, Atmos. Environ., 40, 4316-4327, https://doi.org/10.1016/j.atmosenv.2006.03.040, 2006.

Ducret-Stich, R. E., Tsai, M.-Y., Thimmaiah, D., Kunzli, N., Hopke, P. K., and Phuleria, H. C.: $\mathrm{PM}_{10}$ source apportionment in a Swiss Alpine valley impacted by highway traffic, Environ. Sci. Pollut. Res., 20, 6496-6508, https://doi.org/10.1007/s11356-013-1682$1,2013$.

Dutcher, D. D., Perry, K. D., Cahill, T. A., and Copeland, S. A.: Effects of indoor pyrotechnic displays on the air quality in the Houston Astrodome, J. Air Waste Manage., 49, 156-160, https://doi.org/10.1080/10473289.1999.10463790, 1999.

Efron, B.: Bootstrap methods: Another look at the Jacknife, Ann. Stat., 7, 1-26, 1979.

Empa: Technischer Bericht zum Nationalen Beobachtungsnetz für Luftfremdstoffe (NABEL) 2018, available at: https://www. empa.ch/documents/56101/246436/Technischer+Bericht+2018/ (last access: 21 January 2020), 2018.

Fang, T., Guo, H., Verma, V., Peltier, R. E., and Weber, R. J.: $\mathrm{PM}_{2.5}$ water-soluble elements in the southeastern United States: automated analytical method development, spatiotemporal distributions, source apportionment, and implications for heath studies, Atmos. Chem. Phys., 15, 11667-11682, https://doi.org/10.5194/acp-15-11667-2015, 2015.

Fröhlich, R., Cubison, M. J., Slowik, J. G., Bukowiecki, N., Canonaco, F., Croteau, P. L., Gysel, M., Henne, S., Herrmann, E., Jayne, J. T., Steinbacher, M., Worsnop, D. R., Baltensperger, U., and Prévôt, A. S. H.: Fourteen months of on-line measurements of the non-refractory submicron aerosol at the Jungfraujoch (3580 ma.s.1.) - chemical composition, origins and or- ganic aerosol sources, Atmos. Chem. Phys., 15, 11373-11398, https://doi.org/10.5194/acp-15-11373-2015, 2015.

Fullova, D., Durcanska, D., and Hegrova, J.: Particulate matter mass concentrations produced from pavement surface abrasion, MATEC Web Conf., 117, 00048, https://doi.org/10.1051/matecconf/201711700048, 2017.

Furger, M., Minguillón, M. C., Yadav, V., Slowik, J. G., Hüglin, C., Fröhlich, R., Petterson, K., Baltensperger, U., and Prévôt, A. S. H.: Elemental composition of ambient aerosols measured with high temporal resolution using an online XRF spectrometer, Atmos. Meas. Tech., 10, 2061-2076, https://doi.org/10.5194/amt10-2061-2017, 2017.

Gianini, M. F. D., Fischer, A., Gehrig, R., Ulrich, A., Wichser, A., Piot, C., Besombes, J.-L., and Hueglin, C.: Comparative source apportionment of $\mathrm{PM}_{10}$ in Switzerland for 2008/2009 and $1998 / 1999$ by positive matrix factorisation, Atmos. Environ., 54 , 149-158, https://doi.org/10.1016/j.atmosenv.2012.02.036, 2012.

Grigoratos, T. and Martini, G.: Brake wear particle emissions: a review, Environ. Sci. Pollut. R., 22, 2491-2504, https://doi.org/10.1007/s11356-014-3696-8, 2015.

Harrison, R. M., Beddows, D. C. S., and Dall'Osto, M.: PMF analysis of wide-range particle size spectra collected on a major highway, Environ. Sci. Technol., 45, 5522-5528, https://doi.org/10.1021/es2006622, 2011.

Hassan, A. K., Fares, S., and Abd El-Rahma, M.: Natural radioactivity levels and radiation hazards for gypsum materials used in Egypt. J. Environ. Sci. Technol., 7, 56-66, https://doi.org/10.3923/jest.2014.56.66, 2014.

Hedberg, E., Gidhagen, L., and Johansson, C.: Source contributions to $\mathrm{PM}_{10}$ and arsenic concentrations in Central Chile using positive matrix factorization, Atmos. Environ., 39, 549-561, https://doi.org/10.1016/j.atmosenv.2004.11.001, 2005.

Hueglin, C., Gehrig, R., Baltensperger, U., Gysel, M., Monn, C., and Vonmont, H.: Chemical characterisation of $\mathrm{PM}_{2.5}$, $\mathrm{PM}_{10}$ and coarse particles at urban, near-city and rural sites in Switzerland, Atmos. Environ., 39, 637-651, https://doi.org/10.1016/j.atmosenv.2004.10.027, 2005.

Hueglin, C., Buchmann, B., and Weber, R. O.: Long-term observation of real-world road traffic emission factors on a motorway in Switzerland, Atmos. Environ., 40, 3696-3709, https://doi.org/10.1016/j.atmosenv.2006.03.020, 2006.

Jeong, C.-H., Wang, J. M., and Evans, G. J.: Source Apportionment of Urban Particulate Matter using Hourly Resolved Trace Metals, Organics, and Inorganic Aerosol Components, Atmos. Chem. Phys. Discuss., https://doi.org/10.5194/acp-2016-189, 2016.

Jeong, C.-H., Wang, J. M., Hilker, N., Debosz, J., Sofowote, U., Su, Y., Noble, M., Healy, R. M., Munoz, T., Dabek-Zlotorzynska, E., Celo, V., White, L., Audette, C., Herod, D., and Evans, G. J.: Temporal and spatial variability of traffic-related $\mathrm{PM}_{2.5}$ sources: Comparison of exhaust and non-exhaust emissions, Atmos. Environ., 198, 55-69, https://doi.org/10.1016/j.atmosenv.2018.10.038, 2019.

Ji, D., Cui, Y., Li, L., He, J., Wang, L., Zhang, H., Wang, W., Zhou, L., Maenhaut, W., Wen, T., and Wang, Y.: Characterization and source identification of fine particulate matter in urban Beijing during the 2015 Spring Festival, Sci. Total Environ., 430-440, 628-629, https://doi.org/10.1016/j.scitotenv.2018.01.304, 2018.

Jiang, Q., Sun, Y. L., Wang, Z., and Yin, Y.: Aerosol composition and sources during the Chinese Spring Festival: fireworks, sec- 
ondary aerosol, and holiday effects, Atmos. Chem. Phys., 15, 6023-6034, https://doi.org/10.5194/acp-15-6023-2015, 2015.

Kelly, F. J. and Fussell, J. C.: Air pollution and airway disease, Clin. Exp. Allergy, 41, 1059-1071, https://doi.org/10.1111/j.13652222.2011.03776.x, 2011.

Kelly, F. J. and Fussell, J. C.: Size, source and chemical composition as determinants of toxicity attributable to ambient particulate matter, Atmos. Environ., 60, 504-526, https://doi.org/10.1016/j.atmosenv.2012.06.039, 2012.

Kidwell, C. B. and Ondov, J. M.: Development and evaluation of a prototype system for collecting sub-hourly ambient aerosol for chemical analysis, Aerosol Sci. Tech., 35, 596-601, https://doi.org/10.1080/02786820118049, 2001.

Kim, E. and Hopke, P. K.: Source identifications of airborne fine particles using positive matrix factorization and U.S. Environmental Protection Agency positive matrix factorization, J. Air Waste Manage., 57, 811-819, https://doi.org/10.3155/10473289.57.7.811, 2007.

Kim, E., Hopke, P. K., and Edgerton, E. S.: Source identification of Atlanta aerosol by positive matrix factorization, J. Air Waste Manage., 53, 731-739, https://doi.org/10.1080/10473289.2003.10466209, 2003.

Kim, E., Hopke, P. K., and Qin, Y.: Estimation of organic carbon blank values and error structures of the speciation trends network data for source apportionment, J. Air Waste Manage., 55, 11901199, https://doi.org/10.1080/10473289.2005.10464705, 2005.

Kong, S. F., Li, L., Li, X. X., Yin, Y., Chen, K., Liu, D. T., Yuan, L., Zhang, Y. J., Shan, Y. P., and Ji, Y. Q.: The impacts of firework burning at the Chinese Spring Festival on air quality: insights of tracers, source evolution and aging processes, Atmos. Chem. Phys., 15, 2167-2184, https://doi.org/10.5194/acp15-2167-2015, 2015.

Lanz, V. A., Prévôt, A. S. H., Alfarra, M. R., Weimer, S., Mohr, C., DeCarlo, P. F., Gianini, M. F. D., Hueglin, C., Schneider, J., Favez, O., D'Anna, B., George, C., and Baltensperger, U.: Characterization of aerosol chemical composition with aerosol mass spectrometry in Central Europe: an overview, Atmos. Chem. Phys., 10, 10453-10471, https://doi.org/10.5194/acp-10-104532010, 2010.

Lawrence, S., Sokhi, R., Ravindra, K., Mao, H., Prain, H. D., and Bull, I. D.: Source apportionment of traffic emissions of particulate matter using tunnel measurements, Atmos. Environ., 77, 548-557, https://doi.org/10.1016/j.atmosenv.2013.03.040, 2013.

Lee, D. S. and Pacyna, J. M.: An industrial emissions inventory of calcium for Europe, Atmos. Environ. 33, 1687-1697, https://doi.org/10.1016/S1352-2310(98)00286-6, 1999.

Li, Z., Hopke, P. K., Husain, L., Qureshi, S., Dutkiewicz, V. A., Schwab, J. J., Drewnick, F., and Demerjian, K. L.: Sources of fine particle composition in New York city, Atmos. Environ., 38, 6521-6529, https://doi.org/10.1016/j.atmosenv.2004.08.040, 2004.

Lin, C.-C.: A review of the impact of fireworks on particulate matter in ambient air, J. Air Waste Manage., 66, 1171-1182, https://doi.org/10.1080/10962247.2016.1219280, 2016.

Lin, Y.-C., Tsai, C.-J., Wu, Y.-C., Zhang, R., Chi, K.-H., Huang, Y.-T., Lin, S.-H., and Hsu, S.-C.: Characteristics of trace metals in traffic-derived particles in Hsuehshan Tunnel, Taiwan: size distribution, potential source, and fingerprinting metal ratio, At- mos. Chem. Phys., 15, 4117-4130, https://doi.org/10.5194/acp15-4117-2015, 2015.

Liu, Y., Zheng, M., Yu, M., Cai, X., Du, H., Li, J., Zhou, T., Yan, C., Wang, X., Shi, Z., Harrison, R. M., Zhang, Q., and He, K.: High-time-resolution source apportionment of $\mathrm{PM}_{2.5}$ in Beijing with multiple models, Atmos. Chem. Phys., 19, 6595-6609, https://doi.org/10.5194/acp-19-6595-2019, 2019.

Lucarelli, F., Nava, S., Calzolai, G., Chiari, M., Udisti, R., and Marino, F.: Is PIXE still a useful technique for the analysis of atmospheric aerosols? The LABEC experience, X-Ray Spectrom., 40, 162-167, https://doi.org/10.1002/xrs.1312, 2011.

Maenhaut, W.: Source apportionment revisited for long-term measurements of fine aerosol trace elements at two locations in southern Norway, Nucl. Instrum. Meth. B, 417, 133-138, https://doi.org/10.1016/j.nimb.2017.07.006, 2017.

Manousakas, M., Diapouli, E., Papaefthymiou, H., Migliori, A., Karydas, A. G., Padilla-Alvarez, R., Bogovac, M., Kaiser, R. B., Jaksic, M., Bogdanovic-Radovic, I., and Eleftheriadis, K.: Source apportionment by PMF on elemental concentrations obtained by PIXE analysis of $\mathrm{PM}_{10}$ samples collected at the vicinity of lignite power plants and mines in Megalopolis, Greece, Nucl. Instrum. Meth. B, 349, 114-124, https://doi.org/10.1016/j.nimb.2015.02.037, 2015.

Meister, K., Johansson, C., and Forsberg, B.: Estimated shortterm effects of coarse particles on daily mortality in Stockholm, Sweden, Environ. Health Persp., 120, 431-436, https://doi.org/10.1289/ehp.1103995, 2012.

Minguillón, M. C., Querol, X., Baltensperger, U., and Prévôt, A. S. H.: Fine and coarse PM composition and sources in rural and urban sites in Switzerland: local or regional pollution?, Sci. Total Environ., 427-428, 191-202, https://doi.org/10.1016/j.scitotenv.2012.04.030, 2012.

Moreno, T., Querol, X., Alastuey, A., Minguillón, M. C., Pey, J., Rodriguez, S., Miró, J. V., Felis, C., and Gibbons, W.: Recreational atmospheric pollution episodes: Inhalable metalliferous particles from firework displays, Atmos. Environ., 41, 913-922, https://doi.org/10.1016/j.atmosenv.2006.09.019, 2007.

Ng, N. L., Herndon, S. C., Trimborn, A., Canagaratna, M. R., Croteau, P. L., Onasch, T. B., Sueper, D., Worsnop, D. R., Zhang, Q., Sun, Y. L., and Jayne, J. T.: An aerosol chemical speciation monitor (ACSM) for routine monitoring of the composition and mass concentrations of ambient aerosol, Aerosol Sci. Tech., 45, 780-794, https://doi.org/10.1080/02786826.2011.560211, 2011.

Norris, G., Duvall, R., Brown, S., and Bai, S.: EPA Positive Matrix Factorization (PMF) 5.0 fundamentals and user guide, United States Environmental Protection Agency Office of Research and Development, Washington, DC, 2014.

Paatero, P.: The Multilinear Engine - A table-driven, least squares program for solving multilinear problems, including the $n$-way parallel factor analysis model, J. Comput. Graph. Stat., 8, 854888, https://doi.org/10.1080/10618600.1999.10474853, 1999.

Paatero, P. and Hopke, P. K.: Discarding or downweighting highnoise variables in factor analytic models, Anal. Chim. Acta, 490, 277-289, https://doi.org/10.1016/s0003-2670(02)01643-4, 2003.

Paatero, P. and Tapper, U.: Positive matrix factorization: A non-negative factor model with optimal utilization of error-estimates of data values, Environmetrics, 5, 111-126, https://doi.org/10.1002/env.3170050203, 1994. 
Park, S. S., Cho, S. Y., Jo, M. R., Gong, B. J., Park, J. S., and Lee, S. J.: Field evaluation of a near-real time elemental monitor and identification of element sources observed at an air monitoring supersite in Korea, Atmos. Pollut. Res., 5, 119-128, https://doi.org/10.5094/apr.2014.015, 2014.

Pernigotti, D., Belis, C. A., and Spanó, L.: SPECIEUROPE: The European data base for PM source profiles, Atmos. Pollut. Res., 7, 307-314, https://doi.org/10.1016/j.apr.2015.10.007, 2016.

Perrino, C., Tiwari, S., Catrambone, M., Torre, S. D., Rantica, E., and Canepari, S.: Chemical characterization of atmospheric PM in Delhi, India, during different periods of the year including Diwali festival, Atmos. Pollut. Res., 2, 418-427, https://doi.org/10.5094/apr.2011.048, 2011.

Phillips-Smith, C., Jeong, C.-H., Healy, R. M., DabekZlotorzynska, E., Celo, V., Brook, J. R., and Evans, G.: Sources of particulate matter components in the Athabasca oil sands region: investigation through a comparison of trace element measurement methodologies, Atmos. Chem. Phys., 17, 9435-9449, https://doi.org/10.5194/acp-17-9435-2017, 2017.

Polissar, A. V., Hopke, P. K., Paatero, P., Malm, W. C., and Sisler, J. F.: Atmospheric aerosol over Alaska: 2. Elemental composition and sources, J. Geophys. Res., 103, 19045-19057, https://doi.org/10.1029/98JD01212, 1998.

Pongpiachan, S., Iijima, A., and Cao, J.: Hazard quotients, hazard indexes, and cancer risks of toxic metals in $\mathrm{PM}_{10}$ during firework displays, Atmosphere, 9, 144, https://doi.org/10.3390/atmos9040144, 2018.

Pope III, C. A. and Dockery, D. W.: Health effects of fine particulate air pollution: Lines that connect, J. Air Waste Manage., 56, 709742, https://doi.org/10.1080/10473289.2006.10464485, 2006.

Rahman, S. A., Hamzah, M. S., Wood, A. K., Elias, M. S., Salim, N. A. A., and Sanuri, E.: Sources apportionment of fine and coarse aerosol in Klang Valley, Kuala Lumpur using positive matrix factorization, Atmos. Pollut. Res., 2, 197206,https://doi.org/10.5094/apr.2011.025, 2011.

Rai, P., Chakraborty, A., Mandariya, A. K., and Gupta, T.: Composition and source apportionment of $\mathrm{PM}_{1}$ at urban site Kanpur in India using PMF coupled with CBPF, Atmos. Res., 178-179, 506-520, https://doi.org/10.1016/j.atmosres.2016.04.015, 2016.

Reff, A., Eberly, S. I., and Bhave, P. V.: Receptor modeling of ambient particulate matter data using positive matrix factorization: Review of existing methods, J. Air Waste Manage., 57, 146-154, https://doi.org/10.1080/10473289.2007.10465319, 2007.

Retama, A., Neria-Hernández, A., Jaimes-Palomera, M., Rivera-Hernández, O., Sánchez-Rodríguez, M., LópezMedina, A., and Velasco, E.: Fireworks: a major source of inorganic and organic aerosols during Christmas and New Year in Mexico city, Atmos. Environ.: X, 2, 100013, https://doi.org/10.1016/j.aeaoa.2019.100013, 2019.

Richard, A., Gianini, M. F. D., Mohr, C., Furger, M., Bukowiecki, N., Minguillón, M. C., Lienemann, P., Flechsig, U., Appel, K., DeCarlo, P. F., Heringa, M. F., Chirico, R., Baltensperger, U., and Prévôt, A. S. H.: Source apportionment of size and time resolved trace elements and organic aerosols from an urban courtyard site in Switzerland, Atmos. Chem. Phys., 11, 8945-8963, https://doi.org/10.5194/acp-11-8945-2011, 2011.

Rudnick, R. L. and Gao, S.: Composition of the continental crust, edited by: Rudnick, E., Elsevier Science, Philadelphia, Book Sect. 2, Vol. 3, 1-56, 2003.
Sarkar, S., Khillare, P. S., Jyethi, D. S., Hasan, A., and Parween, M.: Chemical speciation of respirable suspended particulate matter during a major firework festival in India, J. Hazard. Mater., 184, 321-330, https://doi.org/10.1016/j.jhazmat.2010.08.039, 2010.

Schauer, J. J., Lough, G. C., Shafer, M. M, Christensen, W. C., Arndt, M. F., DeMinter, J. T., and Park, J. S.: Characterization of emissions of metals emitted from motor vehicles, Research report Health Effects Institute, 133, 1-76; discussion 77, 2006.

Sofowote U. M., Healy R. M., Su Y., Debosz J., Noble M., Munoz A., Jeong C.-H., Wang J. M., Hilker N., Evans G. J., and Hopke P. K.: Understanding the $\mathrm{PM}_{2.5}$ imbalance between a far and near road location: Results of high temporal frequency source apportionment and parameterization of black carbon, Atmos. Environ., 173, 277-288, https://doi.org/10.1016/j.atmosenv.2017.10.063, 2018.

Taylor, S. R. and McLennan, S. M.: The geochemical evolution of the continental crust, Rev. Geophys., 33, 241-265, 1995.

Thorpe, A. and Harrison, R. M.: Sources and properties of non-exhaust particulate matter from road traffic: A review, Sci. Total Environ., 400, 270-282, https://doi.org/10.1016/j.scitotenv.2008.06.007, 2008.

Tian, S. L., Pan, Y. P., and Wang, Y. S.: Size-resolved source apportionment of particulate matter in urban Beijing during haze and non-haze episodes, Atmos. Chem. Phys., 16, 1-19, https://doi.org/10.5194/acp-16-1-2016, 2016.

Tian, Y. Z., Wang, J., Peng, X., Shi, G. L., and Feng, Y. C.: Estimation of the direct and indirect impacts of fireworks on the physicochemical characteristics of atmospheric $\mathrm{PM}_{10}$ and $\mathrm{PM}_{2.5}$, Atmos. Chem. Phys., 14, 9469-9479, https://doi.org/10.5194/acp14-9469-2014, 2014.

Tremper, A. H., Font, A., Priestman, M., Hamad, S. H., Chung, T.C., Pribadi, A., Brown, R. J. C., Goddard, S. L., Grassineau, N., Petterson, K., Kelly, F. J., and Green, D. C.: Field and laboratory evaluation of a high time resolution $\mathrm{x}$-ray fluorescence instrument for determining the elemental composition of ambient aerosols, Atmos. Meas. Tech., 11, 3541-3557, https://doi.org/10.5194/amt-11-3541-2018, 2018.

Twigg, M. M., Di Marco, C. F., Leeson, S., van Dijk, N., Jones, M. R., Leith, I. D., Morrison, E., Coyle, M., Proost, R., Peeters, A. N. M., Lemon, E., Frelink, T., Braban, C. F., Nemitz, E., and Cape, J. N.: Water soluble aerosols and gases at a UK background site - Part 1: Controls of $\mathrm{PM}_{2.5}$ and $\mathrm{PM}_{10}$ aerosol composition, Atmos. Chem. Phys., 15, 8131-8145, https://doi.org/10.5194/acp-15-8131-2015, 2015.

Ulbrich, I. M., Canagaratna, M. R., Zhang, Q., Worsnop, D. R., and Jimenez, J. L.: Interpretation of organic components from Positive Matrix Factorization of aerosol mass spectrometric data, Atmos. Chem. Phys., 9, 2891-2918, https://doi.org/10.5194/acp-92891-2009, 2009.

Vallius, M.: Characteristics and sources of fine particulate matter in urban air, PhD dissertation, National Public Health Institute, Department of Environmental Health Kuopio, Finland, 2005.

Vecchi, R., Bernardoni, V., Cricchio, D., D’Alessandro, A., Fermo, P., Lucarelli, F., Nava, S., Piazzalunga, A., and Valli, G.: The impact of fireworks on airborne particles, Atmos. Environ., 42, 1121-1132, https://doi.org/10.1016/j.atmosenv.2007.10.047, 2008.

Vega, E., Mugica, V., Reyes, E., Sanchez, G., Chow, J. C., and Watson, J. G.: Chemical composition of fugitive dust 
emitters in Mexico City, Atmos. Environ., 35, 4033-4039, https://doi.org/10.1016/S1352-2310(01)00164-9, 2001.

Visser, S., Slowik, J. G., Furger, M., Zotter, P., Bukowiecki, N., Canonaco, F., Flechsig, U., Appel, K., Green, D. C., Tremper, A. H., Young, D. E., Williams, P. I., Allan, J. D., Coe, H., Williams, L. R., Mohr, C., Xu, L., Ng, N. L., Nemitz, E., Barlow, J. F., Halios, C. H., Fleming, Z. L., Baltensperger, U., and Prévôt, A. S. H.: Advanced source apportionment of size-resolved trace elements at multiple sites in London during winter, Atmos. Chem. Phys., 15, 11291-11309, https://doi.org/10.5194/acp-15-112912015, 2015.

Wahlström, J., Olander, L., and Olofsson, U.: Size, shape, and elemental composition of airborne wear particles from disc brake materials, Tribol. Lett., 38, 15-24, 2010.

Wang, Q., Qiao, L., Zhou, M., Zhu, S., Griffith, S., Li, L., and Yu, J. Z: Source apportionment of $\mathrm{PM}_{2.5}$ using hourly measurements of elemental tracers and major constituents in an urban environment: investigation of timeresolution influence, J. Geophys. Res.: Atmos., 123, 5284-5300, https://doi.org/10.1029/2017JD027877, 2018.

Wang, Y., Zhuang, G., Xu, C., and An, Z.: The air pollution caused by the burning of fireworks during the lantern festival in Beijing, Atmos. Environ., 41, 417-431, https://doi.org/10.1016/j.atmosenv.2006.07.043, 2007.

Yang, L. X., Gao, X. M., Wang, X. F., Nie, W., Wang, J., Gao, R., Xu, P. J., Shou, Y. P., Zhang, Q. Z., and Wang, W. X.: Impacts of firecracker burning on aerosol chemical characteristics and human health risk levels during the Chinese New Year Celebration in Jinan, China, Sci. Total Environ., 476-477, 57-64, https://doi.org/10.1016/j.scitotenv.2013.12.110, 2014.
Yao, L., Wang, D., Fu, Q., Qiao, L., Wang, H., Li, L., Sun, W., Li, Q., Wang, L., Yang, X., Zhao, Z., Kan, H., Xian, A., Wang, G., Xiao, H., and Chen, J.: The effects of firework regulation on air quality and public health during the Chinese Spring Festival from 2013 to 2017 in a Chinese megacity, Environ. Int., 126, 96-106, https://doi.org/10.1016/j.envint.2019.01.037, 2019.

Yu, L., Wang, G., Zhang, R., Zhang, L., Song, Y., Wu, B., Li, X., An, K., and Chu, J.: Characterization and source apportionment of $\mathrm{PM}_{2.5}$ in an urban environment in Beijing, Aerosol Air Qual. Res., 13, 574-583, https://doi.org/10.4209/aaqr.2012.07.0192, 2013.

Zhang, R., Jing, J., Tao, J., Hsu, S.-C., Wang, G., Cao, J., Lee, C. S. L., Zhu, L., Chen, Z., Zhao, Y., and Shen, Z.: Chemical characterization and source apportionment of $\mathrm{PM}_{2.5}$ in Beijing: seasonal perspective, Atmos. Chem. Phys., 13, 7053-7074, https://doi.org/10.5194/acp-13-7053-2013, 2013.

Zhao, W. and Hopke, P. K.: Source apportionment for ambient particles in the San Gorgonio wilderness, Atmos. Environ., 38, 59015910, https://doi.org/10.1016/j.atmosenv.2004.07.011, 2004.

Zhou, S., Davy, P. K., Huang, M., Duan, J., Wang, X., Fan, Q., Chang, M., Liu, Y., Chen, W., Xie, S., Ancelet, T., and Trompetter, W. J.: High-resolution sampling and analysis of ambient particulate matter in the Pearl River Delta region of southern China: source apportionment and health risk implications, Atmos. Chem. Phys., 18, 2049-2064, https://doi.org/10.5194/acp18-2049-2018, 2018. 